\title{
ХИМИЧЕСКИЙ СОСТАВ И ПРАКТИЧЕСКОЕ ПРИМЕНЕНИЕ ЯГОД БРУСники и клюквы
}

\author{
() М.Н. Лютикова", Э.Х. Ботиров \\ Сургутский государственный университет ХМАО-Югры, ул. Ленина, 1, \\ Сургуm, 628412 (Россия) e-mail:m.lyutikova@mail.ru
}

\begin{abstract}
Освещено современное состояние исследований химического состава лесных и культивированных видов ягод брусники (Vaccinium vitis-idaea L.) и клюквы (Oxycoccus palustris, Oxycoccus macrocarpon), произрастающих на территории разных стран. Проведен сравнительный анализ состава ягод внутри каждого вида в разных регионах. Освещена биологическая значимость ягод брусники и клюквы, а также вопросы их практического применения в фармацевтике, народной медицине и некоторых отраслях пищевой промышленности.

Ключевые слова: брусника (Vaccinium vitis-idaea L.), клюква (Oxycoccus palustris, Oxycoccus macrocarpon), органические кислоты, витамины, спирты, альдегиды, кетоны, эфиры, терпеновые соединения, минеральный состав.

Согласно ряду публикаций изучение химического состава ягод брусники и клюквы началось еще с начала XX в. и по настоящее время продолжается исследователями Северной Америки, Канады, Финляндии, Норвегии, Китая, Японии, Белоруссии, России и многих других стран. Высокий научный интерес к изучению метаболитов ягод брусники и клюквы обусловлен давним использованием ягод в народной медицине в качестве жаропонижающего, мочегонного, стимулирующего и тонизирующего средства, для профилактики простудных заболеваний и повышения иммунитета. К настоящему времени выполнено и опубликовано огромное число работ по изучению химического состава плодов брусники и клюквы, подтверждающие содержание широкого спектра питательных и биологически активных веществ [1-12]. Анализ литературы показал, что наиболее широко исследован химический состав брусники обыкновенной, клюквы болотной и культурных сортов клюквы крупноплодной, в некоторых случаях данные приводятся без указания конкретного вида.
\end{abstract}

\section{Степень изученности химического состава ягод брусники и клюквы}

Известно, что каждое растение синтезирует определенный спектр химических соединений в зависимости от многих факторов: температуры окружающей среды, светового потока, состава почвы, относительной влажности воздуха, окислительного стресса и т.д. Иными словами, растение приспосабливается к выживанию, вырабатывает свой «иммунитет». Брусника и клюква - не исключение.

Наиболее распространенным классом органических соединений в растениях являются кислоты. Будучи своего рода связующими звеньями между основными направлениями обмена веществ - углеводным, белковым и жировым, они образуются в результате функционирования циклов окислительного распада углеводов и в процессе фотосинтеза $[13,14]$.

Лютикова Марина Николаевна - соискатель кафедры химии, кандидат химических наук, e-mail:m.lyutikova@mail.ru

Ботиров Эркин Хожсикбарович - заведующий кафедрой химии, професcop, e-mail: botirov-nepi@mail.ru
В ягодах брусники и клюквы различными методами анализа установлен большой набор органических кислот (гидроки-, оксо-, бензойные и фенольные кислоты), на долю которых приходится до $2,0-3,5 \%$ сырой массы (табл. 1) [11, 12, 15].

\footnotetext{
* Автор, с которым следует вести переписку.
} 
Таблица 1. Кислотный состав спелых ягод брусники и клюквы (г или мг/100 г свежих ягод)

\begin{tabular}{|c|c|c|c|}
\hline \multirow{2}{*}{$\begin{array}{c}\text { Компонент } \\
\text { (номер структурной формулы) }\end{array}$} & \multirow{2}{*}{ Vaccinium vitis-idaea $\mathrm{L}$. } & \multicolumn{2}{|c|}{ Oxycoccus } \\
\hline & & palustris (осенняя) & macrocarpon \\
\hline Лимонная кислота & 1,28 г $[12,40]$ & $1,8-2,6$ г $[11]$ & $1,1 г[11]$ \\
\hline Яблочная кислота & 0,30 г $[12,40]$ & - & - \\
\hline Урсоловая кислота (7) & 750 мг $[8,33]$ & $100-150$ мг [34] & - \\
\hline Олеаноловая кислота (8) & - & 29-40 мг [34] & - \\
\hline Бензойная кислота (11) & $73-158$ мг $[24,36,40]$ & $11-63$ мг [11] & $65-123$ мг [11] \\
\hline Галловая кислота (12) & $1,1-4,4$ мг [36] & Не обнаружена [36] & - \\
\hline Сиринговая кислота (13) & Не обнаружена [36] & 0,99 мг [36] & - \\
\hline n-гидроксибензойная кислота (14) & 1,34 мг [36] & Не обнаружена [36] & 2,16 мг [25] \\
\hline Протокатеховая кислота (15) & 4,42 мг [36] & 2,35 мг [36] & - \\
\hline Ванилиновая кислота (16) & 0,9 мг [36] & 3,1 мг [36] & 1,9 мг [25] \\
\hline Коричная кислота (17) & 3,6 мг [36] & 0,49 мг [36] & 2,05 мг [25] \\
\hline Феруловая кислота (18) & 1,5 мг [36] & 0,6 мг [36] & 8,8 мг [25] \\
\hline Кофейная кислота (19) & 4,5 мг [36] & 2,3 мг [36] & 15,6 мг [25] \\
\hline Синаповая кислота (20) & 0,26 мг [36] & 0,52 мг [36] & 21,18 мг [25] \\
\hline$n$-кумаровая кислота (21) & 3,5 мг [36] & 1,4 мг [36] & 2,54 мг [25] \\
\hline o-гидроксибензойная кислота (22) & 7,8 мг [36] & - & 2,32 мг [25] \\
\hline м-гидроксибензойная кислота (23) & - & - & 0,91 мг [25] \\
\hline$n$-гидроксифенилуксусная кислота (24) & - & - & 0,74 мг [25] \\
\hline 2,3-дигидроксибензойная кислота (25) & - & - & 0,32 мг [25] \\
\hline 2,4-дигидроксибензойная кислота (26) & - & - & 4,25 мг [25] \\
\hline o-фталевая кислота (27) & - & - & 1,57 мг [25] \\
\hline o-гидроксикоричная кислота (28) & Следы [16] & Следы $[17,18]$ & 89,1 мг [25] \\
\hline Хлорогеновая кислота (29) & 2,84 мг [36] & 7,2 мг [11] & 8,8 мг [11] \\
\hline Молочная кислота & $0,13-0,31$ мг [16] & $0,44-0,98$ мг $[17,18]$ & - \\
\hline 2-метилмасляная кислота & $2,61-3,78$ мг [16] & $0,99-4,59$ мг $[17,18]$ & - \\
\hline Изовалериановая кислота & $0,17-1,52$ мг [16] & 0,16 мг $[17,18]$ & - \\
\hline Левулиновая кислота & $0,04-0,98$ мг [16] & $0,19-0,37$ мг $[17,18]$ & - \\
\hline$\alpha$-кетоглутаровая & $0,22-0,72$ мг [16] & $0,13-0,76$ мг $[17,18]$ & - \\
\hline 4-кетопимелиновая & $0,12-0,88$ мг [16] & $0,37-0,53$ мг $[17,18]$ & - \\
\hline Янтарная & $0,06-0,13$ мг [16] & $0,34-0,98$ мг $[17,18]$ & - \\
\hline Капроновая & $0,8-6,5$ мг $[16,20]$ & 0,4-7,4 мг [17-20] & - \\
\hline Пеларгоновая & $3,0-7,9$ мг $[16,20]$ & $5,6-12,8$ мг [17-20] & - \\
\hline Каприновая & $0,8-2,2$ мг $[16,20]$ & $1,2-1,9$ мг [17-20] & - \\
\hline Ундекановая & $1,0-4,2$ мг $[16,20]$ & $1,1-2,0$ мг [17-20] & - \\
\hline Лауриновая & $1,2-5,3$ мг $[16,20]]$ & $0,9-2,1$ мг [17-20] & - \\
\hline Тридекановая & $0,8-4,5$ мг $[16,20]$ & $1,8-5,9$ мг [17-20] & - \\
\hline Миристиновая & $15,9-47,3$ мг $[16,20]$ & 1,6-11,1 мг [17-20] & - \\
\hline Пентадекановая & $0,4-2,9$ мг $[16,20]$ & $0,8-2,0$ мг [17-20] & - \\
\hline Пальмитиновая & $9,2-22,5$ мг $[16,20]$ & $3,4-34,6$ мг [17-20] & - \\
\hline Маргариновая & $0,15-2,65$ мг $[16,20]$ & $1,0-4,2$ мг [17-20] & - \\
\hline Стеариновая & $6,4-7,4$ мг $[16,20]$ & $1,3-28,0$ мг [17-20] & - \\
\hline Арахиновая & 0,89 мг $[16,20]$ & 0,2-2,1 мг [17-20] & - \\
\hline Пальмитолеиновая & 3,11 мг $[16,20]$ & $0,5-1,9$ мг [17-20] & - \\
\hline Олеиновая & $13,2-15,5$ мг $[16,20]$ & $12,2-34,2$ мг [17-20] & - \\
\hline Линолевая & $14,6-16,3$ мг $[16,20]$ & 9,5-20,8 мг [17-20] & - \\
\hline Линоленовая & $0,9-1,2$ мг $[16,20]$ & $4,6-6,9$ мг [17-20] & - \\
\hline Салициловая & $1,7-3,1$ мг [16] & $0,5-1,4$ мг $[17,20]$ & - \\
\hline$\alpha$-резорциловая & 0,9 мг [16] & 1,2 мг $[17,20]$ & - \\
\hline$n$-третбутилбензойная & $1,6-4,4$ мг [16] & $1,1-8,4$ мг $[17,20]$ & - \\
\hline Гомоанисовая & $0,8-1,0$ мг [16] & $0,1-0,5$ мг $[17,20]$ & - \\
\hline Гомованилиновая & $0,5-0,7$ мг [16] & $0,1-1,5$ мг $[17,20]$ & - \\
\hline Гомосирингиновая & $0,5-0,8$ мг [16] & $0,7-0,9$ мг $[17,20]$ & - \\
\hline Фенилглиоксиловая & Следы [16] & Следы $[17,20]$ & - \\
\hline n-метоксиманделиновая & Следы [16] & Следы [17, 20] & - \\
\hline 2-оксо-4-фенил-3-бутеновая & $0,3-0,9$ мг [16] & $0,1-0,7$ мг $[17,20]$ & - \\
\hline a,4-дигидроксифенилпропановая & Следы [16] & Следы $[17,20]$ & - \\
\hline
\end{tabular}

Примечание: в круглых скобках указан номер структурной формулы соединения. 
Преобладающими кислотами брусники и клюквы являются лимонная и яблочная. При этом анализируя литературные данные, можно отметить их вариабельность в зависимости от вида, времени сбора, места произрастания ягод. В зрелых плодах брусники содержание лимонной и яблочной кислот достигает 1,28 и 0,30 г на 100 г свежих ягод соответственно. В клюкве самое высокое содержание лимонной кислоты отмечено в ранние сроки сбора ягод клюквы (конец первой декады августа) - 4,5 г. В последующие сроки сбора ее содержание уменьшается до 1,8-2,6 г/100 г [7].

В ранних публикациях по исследованию кислотного состава свежих плодов брусники и клюквы приводится информация о незначительных количествах щавелевой, винной, салициловой, уксусной, пировиноградной, глиоксиоловой, $\gamma$-окси- $\alpha$-кетомасляной и $\alpha$-кетоглутаровой кислот $[6-8,11,12]$.

Установлен и жирно-кислотный состав ягод брусники и клюквы [16-21]. В работах показано, как меняется концентрация насыщенных и ненасыщенных жирных кислот в зависимости от места произрастания ягод на северных территориях Тюменской области. Жирные кислоты входят в состав ацильных липидов растительной ткани и таким образом участвуют в повышении устойчивости растений к низким температурам [13-14].

Брусника и клюква имеют в своем составе бензойную кислоту, которая обладает антисептическим действием и, вероятно, защищает ягоды от плесеней [22]. Первые упоминания о наличии бензойной кислоты в ягодах клюквы привел в 1905 году в своей статье американский ученый G.F. Mason [23]. Позже рядом зарубежных и отечественных исследователей, с помощью современных методов анализа были определены количественные содержания этого вещества. Так, установлено, что в бурой бруснике содержание бензойной кислоты составляет 38 мг\%, клюкве болотной - 39 мг\%, в зрелых, соответственно, - 73-158 мг\% и 1163 мг\% [11, 12, 24]. Крупноплодная клюква по уровню накопления бензойной кислоты превосходит клюкву болотную (65-470 мг\%) [25]. Существенное влияние на количество бензойной кислоты оказывают эдафические условия произрастания, погодные особенности вегетационного периода и ряд других факторов $[11,12,26,27]$.

В бруснике обыкновенной и клюкве болотной бензойная кислота находится не только в свободном, но и в связанном состоянии - в виде гликозида вакцинина (6-бензоилглюкоза), который расщепляется на $\alpha$-глюкозу и бензойную кислоту. Количество свободной бензойной кислоты колеблется от 54 до 144 мг\%, а количество вакцинина - от 34 до 124 мг\% [8]. В отличие от бензойной кислоты в свободном состоянии вакцинин не обладает антисептическими свойствами. В состав ягод брусники и клюквы входит еще один гликозид - арбутин (1) (гидрохинон- $\beta$-D-глюкопиранозид). Содержание арбутина (1) в процессе созревания ягод уменьшается в 3-4 раза (от 1100-1610 мг\% в зеленых ягодах до 290-380 мг\% в спелых) [26]. Г.А. Богдановой [26] отмечается, что с увеличением освещенности и сухости почв место произрастаний брусники количество арбутина (1) и танидов в ее вегетативных частях увеличивается. В организме арбутин (1) расщепляется на глюкозу и гидрохинон, последний обладает бактерицидными свойствами $[7,8]$.

Канадскими учеными в ягодах клюквы болотной найдены следы лептозина (2) [28].

В ягодах брусники обыкновенной, клюквы болотной и крупноплодной исследователями из Исландии были выделены и установлены методами масс-спектрометрии и ЯМР-спектроскопии структуры иридоидов - монотропеин (3) и 6,7-дигидромонотропеин (4) (сплендозид) [29].<smiles>OC[C@H]1O[C@H](Oc2ccc(O)cc2)[C@H](O)[C@H](O)[C@H]1O</smiles><smiles>COc1c(O[C@@H]2O[C@H](CO)[C@@H](O)C[C@H]2O)ccc2c1O/C(=C\c1ccc(O)c(O)c1)C2=O</smiles> 


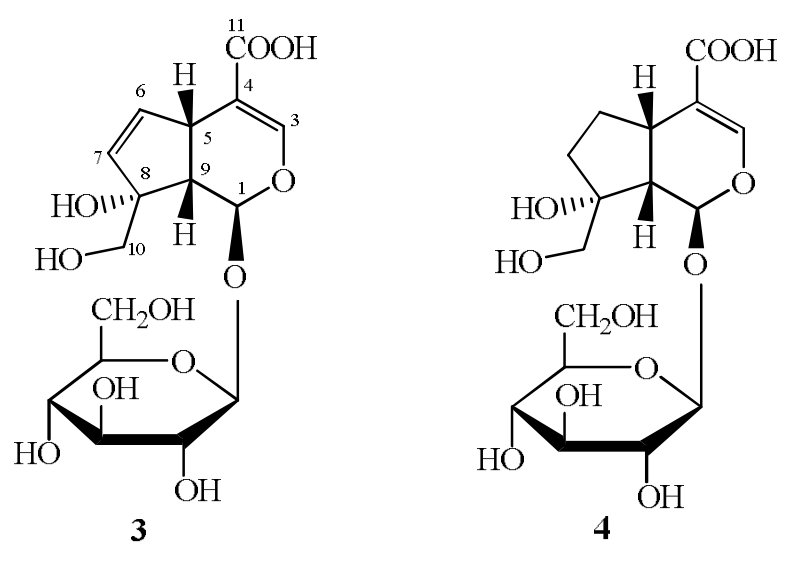

В результате совместной работы ученых из Финляндии и Турции [30] с применением хромато-масс-спектрометрического метода выяснен химический состав кожицы ягод брусники обыкновенной и клюквы болотной. Главным компонентом кутикулы ягод является растворимый и нерастворимый кутин, а также растворимый кутикулярный воск. Растворенного кутина в кожице ягод брусники - 30\%, в кожице ягод клюквы - $27 \%$. При этом преобладающими соединениями - мономерами кутина - являются $\mathrm{C}_{16}-\mathrm{C}_{18}$-кислоты с функциональными эпокси- и гидроксигруппами. Так, основные идентифицированные кислоты кожицы ягод брусники и клюквы - 9,10-эпокси-18-

гидроксиоктадека-12-еновая, 9,10-эпокси-18-гидроксиоктадекановая, 16-гидроксигексадекановая, 18гидроксиоктадека-9-еновая, 10,16-дигидроксигексадекановая, 9,16-дигидроксигексадекановая, 8,16-дигидроксигексадекановая, 9,10,18-тригидроксиоктадека-12-еновая, 9,10,18-тригидроксиоктадекановая. Последняя кислота обнаружена только в клюкве. Общее содержание эпокси- и гидроксикислот кожицы ягод брусники и клюквы 95 и 97\% соответственно. Остальные 5 и 3\% составляют ароматические компоненты, глицерин, дикарбоновые кислоты, длинноцепочечные алифатические кислоты и спирты.

Е.А. Романова, используя в своих исследованиях газовую хромато-масс-спектрометрию, идентифицировала в семенах клюквы ряд органических соединений - олеиновая, стеариновая, миристиновая, пальмитиновая, линолевая, линоленовая, бегеновая кислоты, а также токоферол (витамин Е), кампестерин (5) и $\beta$-ситостерин (6) [31]. Вероятно, авторы ошибочно отнесли соединения 5 и 6 к провитаминам D, на самом деле провитаминами D являются эргостерин и холестерин. Несомненно одно: данные соединения относятся к биологически важным соединениям, поскольку играют структурную роль в составе клеточных мембран [32].

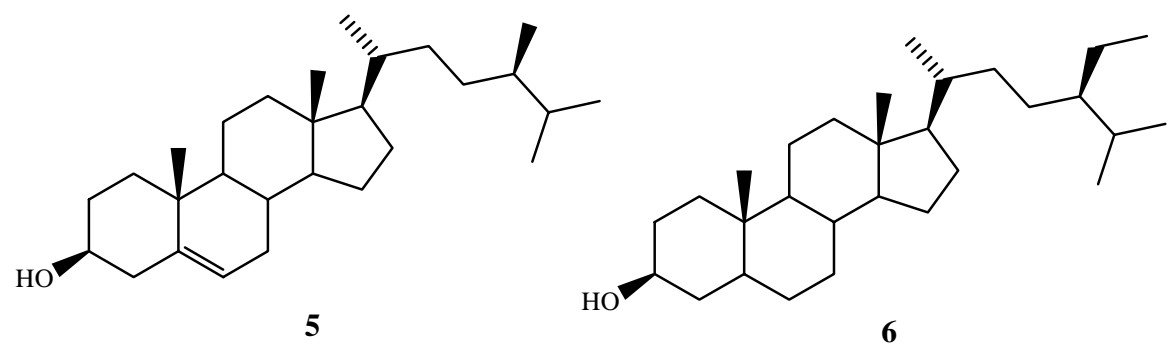

Тритерпеноиды, содержащиеся в ягодах, листьях и побегах брусники и клюквы, представлены преимущественно урсоловой (7) и олеановой (8) кислотами, для которых выявлены несколько типов противоопухолевой и других видов биологической активности. Исследования, проведенные авторами [33] в 2006 г. с использованием ВЭЖХ и ХМС-анализа показали, что тритерпеновые кислоты плодов брусники и клюквы в основном содержатся в эпикутикулярных оболочках ягод. Кожица ягод брусники содержит до 750 мг\% урсоловой (7) кислоты. В клюкве содержание урсоловой (7) кислоты колеблется от 100 до 150 мг\% свежего сырья, олеаноловой (8) - 29-40 мг\% соответственно. По сравнению с семенами оболочки в 6-7 раз богаче урсоловой (7) и в 4 раза - олеаноловой $(8)$ кислотами. Сок и мякоть брусники и клюквы тритерпеновых кислот практически не содержат [8, 33, 34].

Канадскими исследователями из ягод клюквы крупноплодной выделены Z- (9) и Е- (10) изомер сложного эфира $n$-гидроксикоричной и урсоловой кислот (3-О- $n$-гидроксициннамоилурсоловая кислота), проявляющий противоопухолевую активность [35].

Брусника и клюква являются весьма ценным источником фенольных и полифенольных соединений. К ним относятся антоцианы, лейкоантоцианы, катехины, флавонолы и фенолокислоты, отличающиеся Рвитаминным действием и поэтому часто называемые биофлавоноидами (витамин Р). 
<smiles></smiles>

7

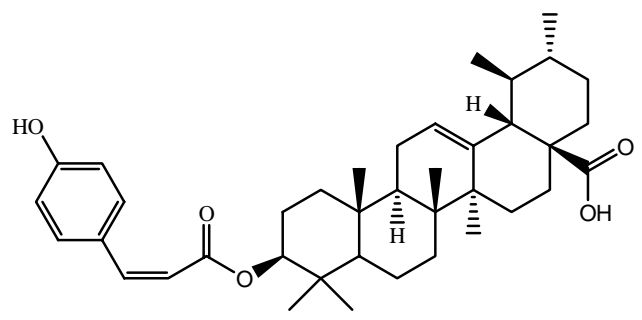

9<smiles>CC1(C)CC[C@@]2(C(=O)O)CC[C@]3(C)C(=CC[C@@H]4[C@@]5(C)CC[C@H](O)C(C)(C)C5CC[C@]43C)[C@H]2C1</smiles>

8

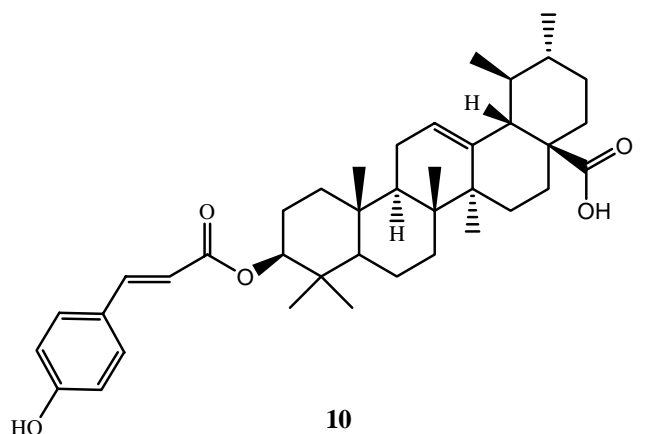

Фенольные кислоты в растении в основном присутствуют в связанном состоянии в виде эфиров или гликозидов. Финляндскими исследователями методом ВЭЖХ установлено, что ягоды брусники обыкновенной и клюквы болотной содержат в качестве агликонов следующие фенольные кислоты: галловой (12), сиринговой (13), n-гидроксибензойной (14), протокатеховой (15), ванилиновой (16), транс-коричной (17), феруловой (18), кофейной (19), синаповой (20), n-кумаровой (21) [36]. Общее количество фенольных кислот в ягодах брусники обыкновенной и клюквы болотной составляет 24 и 12 мг\% сырого веса соответственно [36]. В крупноплодной клюкве из Северной Америки, кроме перечисленных выше кислот, методом газовой хроматографии с масс-селективным детектором идентифицированы также $о$-гидроксибензойная (22), м-гидроксибензойная (23), $n$-гидроксифенилуксусная (24), 2,3-дигидроксибензойная (25), 2,4-дигидроксибензойная (26), o-фталевая (27), o-гидроксикоричная (28) кислоты [25]. Авторами [25, 36] отмечается, что бензойные и фенольные кислоты в ягодах в большей степени находятся в связанной форме (54\% - от общего содержания бензойных и фенольных кислот). Проведение кислотного и щелочного гидролиза при пробоподготовке растительного материала позволяет высвободить и определить кислоты в свободном состоянии, что отражается на результатах количественного анализа. Так, выяснено, что концентрация бензойной (11) кислоты в ягодах американской клюквы до гидролиза составляет 48,1 мг\%, после гидролиза 474,1 мг\% сырого веса. Общее содержание бензойных и фенольных кислот клюквы крупноплодной более 570 мг\% сырого веса ягод [25].

Как показали исследования [37], отходы переработки ягод клюквы могут быть ценным источником получения свободных фенольных соединений, обладающих антиокислительными свойствами. Обнаружено, что выжимки клюквы, состоящие из кожицы и семян, содержат до 50 мг\% фенольных кислот, в том числе галловая (12) (1,13 мг\%), $n$-гидроксибензойная (14) (1,42 мг\%), хлорогеновая (29) (0,5 мг\%), кумаровая (21) (0,67 мг\%). В следовых количествах идентифицированы гентизиновая (30), ванилиновая (16), феруловая (18), коричная (17) кислоты.

По разным литературным данным, в спелых плодах брусники содержание полифенольных соединений колеблется в широких пределах - от 500 до 1910 мг\%. Концентрации веществ, которые относятся к полифенолам брусники, также претерпевают существенные вариации - антоцианы 180-530 мг\%, лейкоантоцианы 150-1060 мг\%, катехины 50-1090 мг\% (табл. 2) [8, 38-43]. Содержание флавонолов (31-33) в бруснике составляет 215-263 мг\% свежих ягод. В бруснике обыкновенной из флавонолов обнаружен кверцетин (31) в количестве 11,3 мг\% сырого продукта [44]. В бруснике из Японии кверцетина (31) содержится 2,46 мг\%, мирицетина (32) - 3,89 мг\%, а кемпферола (33) - 0,5 мг\% [45]. 
<smiles>[R]c1cc(C(=O)O)c([R])c([R])c1[R]</smiles>

11: $R_{1}=R_{2}=R_{3}=R_{4}=H$

12: $R_{1}=H, R_{2}=R_{3}=R_{4}=O H$

13: $\mathrm{R}_{1}=\mathrm{H}, \mathrm{R}_{2}=\mathrm{R}_{4}=\mathrm{OCH}_{3}, \mathrm{R}_{3}=\mathrm{OH}$

14: $\mathrm{R}_{1}=\mathrm{R}_{2}=\mathrm{R}_{4}=\mathrm{H}, \mathrm{R}_{3}=\mathrm{OH}$

15: $\mathrm{R}_{1}=\mathrm{R}_{4}=\mathrm{H}, \mathrm{R}_{2}=\mathrm{R}_{3}=\mathrm{OH}$

16: $\mathrm{R}_{1}=\mathrm{R}_{4}=\mathrm{H}, \mathrm{R}_{2}=\mathrm{OCH}_{3}, \mathrm{R}_{3}=\mathrm{OH}$

22: $\mathrm{R}_{1}=\mathrm{OH}, \mathrm{R}_{2}=\mathrm{R}_{3}=\mathrm{R}_{4}=\mathrm{H}$

23: $\mathrm{R}_{1}=\mathrm{R}_{3}=\mathrm{R}_{4}=\mathrm{H}, \mathrm{R}_{2}=\mathrm{OH}$

25: $\mathrm{R}_{1}=\mathrm{R}_{2}=\mathrm{OH}, \mathrm{R}_{3}=\mathrm{R}_{4}=\mathrm{H}$

26: $\mathrm{R}_{1}=\mathrm{R}_{3}=\mathrm{OH}, \mathrm{R}_{2}=\mathrm{R}_{4}=\mathrm{H}$

27: $\mathrm{R}_{1}=\mathrm{COOH}, \mathrm{R}_{2}=\mathrm{R}_{3}=\mathrm{R}_{4}=\mathrm{H}$

30: $\mathrm{R}_{1}=\mathrm{R}_{4}=\mathrm{OH}, \mathrm{R}_{2}=\mathrm{R}_{3}=\mathrm{H}$<smiles>[R]c1cc(/C=C/C(=O)O)c([R])c([R])c1[R]</smiles><smiles>O=C(O)Cc1ccc(O)cc1</smiles>

17: $\mathrm{R}_{1}=\mathrm{R}_{2}=\mathrm{R}_{3}=\mathrm{R}_{4}=\mathrm{H}$

18: $R_{1}=R_{4}=H, R_{2}=O C H$

19: $\mathrm{R}_{1}=\mathrm{R}_{4}=\mathrm{H}, \mathrm{R}_{2}=\mathrm{R}_{3}=\mathrm{OH}$

20: $\mathrm{R}_{1}=\mathrm{H}, \mathrm{R}_{2}=\mathrm{R}_{4}=\mathrm{OCH}_{3}, \mathrm{R}_{3}=\mathrm{OH}$

21: $\mathrm{R}_{1}=\mathrm{R}_{2}=\mathrm{R}_{4}=\mathrm{H}, \mathrm{R}_{3}=\mathrm{OH}$

28: $\mathrm{R}_{1}=\mathrm{OH}, \mathrm{R}_{2}=\mathrm{R}_{3}=\mathrm{R}_{4}=\mathrm{H}$<smiles>O=C(/C=C/c1ccc(O)c(O)c1)O[C@@H]1C[C@@](O)(C(=O)O)C[C@H](O)[C@H]1O</smiles>

29

В клюкве болотной максимальное количество полифенолов наблюдается в конце первой - начале второй декады августа, а затем резко снижается. Соотношение между отдельными группами флавоноидов зависит от степени зрелости сырья. Концентрация флавоноидов в плодах клюквы в стадии съемной зрелости в октябре составляет 2000-2500 мг\% сухого вещества. Концентрация флавонолов в недозрелой клюкве - 152, клюкве средней степени зрелости - 137, зрелой - 114 мг\%, антоцианов - 91, 150, 163 и лейкоантоцианов - 95, 116, 125 мг\% соответственно [46]. По данным польских авторов [47], общее содержание фенольных веществ в клюкве болотной достигает 206 мг\%, антоцианина - 28 мг\%. В клюкве кверцетина (31) чуть больше, чем в бруснике - 14 мг\%. Кроме того, в плодах клюквы содержатся другие представители класса флавонолов - мирицетин (32) (4,3 мг\%) и кемпферол (33) (0,1 мг\%) [44]. По данным японских авторов [45], в ягодах клюквы крупноплодной концентрация кверцетина (31) и кемпферола (33) составляет, соответственно, 14 и 0,64 мг\% сырого веса ягод.

Исследователями из Университета им. Oulu, P.O. (Финляндия) [48], приводится следующий состав флавонолов брусники обыкновенной: кверцетин-3-O- $\beta$-галактозид (34), кверцетин-3-O- $\beta$-глюкозид (35), кверцетин-3-O- $\alpha$-арабинопиранозид $\quad(\mathbf{3 6}), \quad$ кверцетин-3-O- $\alpha$-арабинофуранозид $\quad(37), \quad$ кверцетин-3-O- $\beta$ ксилопиранозид (38), кверцетин-3-O- $\alpha$-рамнозид $\quad(39)$, мирицетин-3-O- $\beta$-ксилопиранозид $\quad(\mathbf{4 0}), \quad 3$ 'метоксикверцетин-3- $\alpha$-ксилопиранозид (41). Кроме перечисленных соединений зарубежными авторами [48] в ягодах брусники обыкновенной методом жидкостной хроматографии с тройной квадрупольной массспектрометрией идентифицированы и другие фенольные соединения - кверцетин-3-O-(6"-n-кумароил)- $\beta$ галактозид $\quad \mathbf{( 4 2 ) ,} \quad$ кверцетин-3-O-(6"-бензоил)- $\beta$-галактозид $\quad(\mathbf{4 3}), \quad$ кверцетин-3-O-(4"-3-гидрокси-3метилглутароил)- $\alpha$-рамнозид (44), 2-кофеоиларбутин (45).

В статье [49] приводится информация о содержании в ягодах клюквы крупноплодной природного антиоксиданта - резвератрола (3,5,4'-тригидроксистильбен) $(\mathbf{4 6}, \mathbf{4 7})$, который был выделен после ферментативного гидролиза (Z- и $E$-форма).

Факторы окружающей среды (свет, температура и питательные вещества почвы) могут оказывать влияние на фенилпропановый метаболизм и концентрацию флавонолов. По данным авторов из НьюДжерси [50], содержание флавонолов в ягодах клюквы крупноплодной из Восточной Финляндии составляет в 1,7 раза больше, чем из Западной Финляндии.

Дубильные вещества сосредоточены, главным образом, в оболочках плодов, причем в недозрелых плодах их обычно больше, чем в спелых. Среднее содержание дубильных веществ в ягодах брусники и клюквы колеблется от 100 до 400 мг\%, при этом основную часть составляет танин (табл. 2) [11,40]. Известно, что содержание танина в плодах уменьшается по мере созревания, поэтому в брусничном и клюквенном соках его количество невелико [51]. В небольшом количестве присутствует галловая кислота. В перезимовавшей клюкве содержание полифенолов и дубильных веществ по сравнению с показателями осенних ягод снижается [6]. 
Таблица 2. Фенольный состав спелых ягод брусники и клюквы (мг/100 г свежих ягод)

\begin{tabular}{|c|c|c|c|}
\hline \multirow{2}{*}{ Компонент } & \multirow{2}{*}{ Vaccinium vitis-idaea L. } & \multicolumn{2}{|c|}{ Oxycoccus } \\
\hline & & palustris (осенняя) & macrocarpon \\
\hline Дубильные вещества & $160-380[40]$ & $100-320[11,40]$ & - \\
\hline Танины & - & - & $100[82]$ \\
\hline Полифенольные соединения & $500-1910[8,40]$ & $300-600[11]$ & - \\
\hline Фенольные вещества & $82[45]$ & $206[47]$ & $1720[40] ; 86[45]$ \\
\hline Флавонолы & $215-263[44]$ & $114-300[11,46]$ & 14-349 [11] \\
\hline Кверцетин (31) & $2,5-11,3[44,45]$ & $14[44]$ & $14[45]$ \\
\hline Мирицетин (32) & $3,9[45]$ & $4,3[44]$ & - \\
\hline Кемпферол (33) & $0,5[45]$ & $0,1[44]$ & $0,64[45]$ \\
\hline Флаван-3-олы & - & - & $6-20[82]$ \\
\hline Антоцианины & $6,85[45]$ & $28,3[47]$ & $3,6-172[45,53,82]$ \\
\hline Антоцианы & $180-530[8,39]$ & $0,28-0,682 \%[11,39,46]$ & $80-760[8,39]$ \\
\hline Лейкоантоцианы & $150-1060[8,39]$ & $125-1700[11,39,46]$ & $110[39]$ \\
\hline Катехины & 50-1090 [8, 38, 39] & 160-990 [11, 38, 39] & $374-390[11,39]$ \\
\hline
\end{tabular}

Примечание: «-»- нет данных о количественном содержании; в квадратных скобках приведены литературные ссылки; в круглых скобках указан номер структурной формулы соединения; концентрации веществ приведены на сырую массу ягод.<smiles>[R]c1cc(-c2oc3cc(O)cc(O)c3c(=O)c2O)cc([R])c1O</smiles>

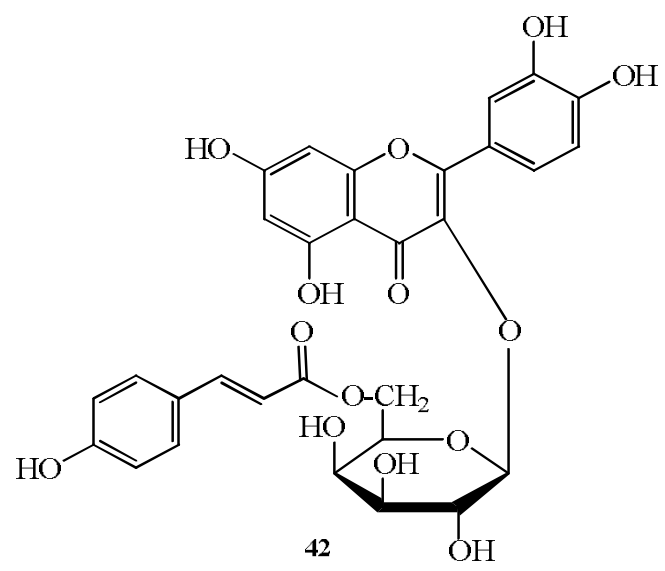<smiles></smiles>

31: $\mathrm{R}_{1}=\mathrm{OH}, \mathrm{R}_{2}=\mathrm{R}_{3}=\mathrm{H}$

32: $\mathrm{R}_{1}=\mathrm{R}_{2}=\mathrm{OH}, \mathrm{R}_{3}=\mathrm{H}$

33: $\mathrm{R}_{1}=\mathrm{R}_{2}=\mathrm{R}_{3}=\mathrm{H}$

34: $\mathrm{R}_{1}=\mathrm{OH}, \mathrm{R}_{2}=\mathrm{H}, \mathrm{R}_{3}=$ Gal

35: $\mathrm{R}_{1}=\mathrm{OH}, \mathrm{R}_{2}=\mathrm{H}, \mathrm{R}_{3}=\mathbf{G l c}$

36: $\mathrm{R}_{1}=\mathrm{OH}, \mathrm{R}_{2}=\mathrm{H}, \mathrm{R}_{3}=$ Ara

37: $\mathrm{R}_{1}=\mathrm{OH}, \mathrm{R}_{2}=\mathrm{H}, \mathrm{R}_{3}=$ Ara

38: $\mathrm{R}_{1}=\mathrm{OH}, \mathrm{R}_{2}=\mathrm{H}, \mathrm{R}_{3}=\mathbf{X y l}$

39: $\mathrm{R}_{1}=\mathrm{OH}, \mathrm{R}_{2}=\mathrm{H}, \mathrm{R}_{3}=\mathbf{R h a}$

40: $\mathrm{R}_{1}=\mathrm{OH}, \mathrm{R}_{2}=\mathrm{OH}, \mathrm{R}_{3}=\mathbf{X y l}$

41: $\mathrm{R}_{1}=\mathrm{OCH}_{3}, \mathrm{R}_{2}=\mathrm{H}, \mathrm{R}_{3}=\mathbf{X y l}$

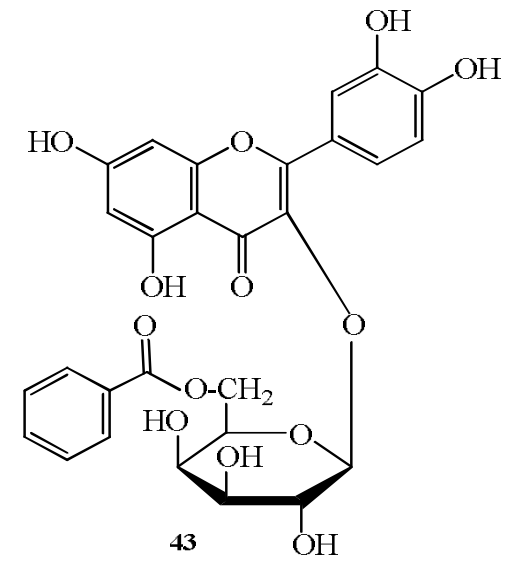<smiles>O=C(/C=C/c1ccc(O)c(O)c1)OC[C@H](O)[C@@H](O)[C@H](O)Oc1ccc(O)cc1</smiles>

45 
<smiles>Oc1ccc(/C=C\c2cc(O)cc(O)c2)cc1</smiles>

46<smiles>Oc1ccc(/C=C/c2cc(O)cc(O)c2)cc1</smiles>

47

Количество катехинов, содержащееся в ягодах, в процессе созревания уменьшается на 36-57\% в зависимости от погодно-климатических условий. По данным авторов [52], качественный состав катехинов при созревании ягод не остается постоянным. Так, эпигалло-катехин-галлат (48) присутствует в бруснике всех стадий зрелости, галлокатехин (49) - в зеленой и бурой, эпигалло-катехин (50) - только в зеленой. Клюква во всех стадиях зрелости, в том числе подснежная, имеет в своем составе галлокатехин (49) и эпикатехин (51). Эпигалло-катехин (50) в подснежной клюкве отсутствует. В зеленой и подснежной клюкве найден эпигалло-катехин-галлат (48).

Красящие вещества ягод представлены хлорофиллом, каротиноидами и антоцианами. Зеленые ягоды содержат только хлорофилл и каротиноиды, в бурых есть все три группы пигментов, а в зрелых - каротиноиды и антоцианы.

Некоторыми исследователями $[48,52,53]$ приводится следующий состав антоцианов дикорастущих ягод: антоцианы брусники обыкновенной, клюквы осенней и подснежной - цианидин-3-галактозид (52), пеонидин-3-галактозид (53), цианидин-3-арабинозид (54), пеонидин-3-арабинозид (55); брусники - цианидин-3-галактозид (52), цианидин-3-глюкозид (56). Из перечисленных соединений самой сильной окислительной способностью обладает цианидин-3-глюкозид (56) [54].

Среднее значение содержания антоцианов клюквы крупноплодной в пересчете на цианидин-3глюкозид (56) составляет 80 мг\% сырого веса [55]. При этом антоцианы клюквы главным образом представлены цианидин-3-галактозидом (52), цианидин-3-глюкозидом (56), цианидин-3-арабинозидом (55), пеонидин-3-галоктозидом (53), пеонидин-3-арабинозидом (55) и пеонидин-3-глюкозидом (57) [46, 52, 53, $55,56]$. Красный цвет клюквы является следствием присутствия четырех основных антоцианов: цианидин3-арабинозид (54), пеонидин-3-арабинозид (55), цианидин-3-галактозид (52), пеонидин-3-галоктозид (53). Последний содержится в клюкве в наибольшем количестве [53].<smiles>[R]c1cc([C@H]2Oc3cc(O)cc(O)c3CC2[R2])cc(O)c1O</smiles>

49: $\mathrm{R}_{1}=\mathrm{OH}, \mathrm{R}_{2}=-\mathrm{OH}$<smiles>[R]O[R]=[R]</smiles>

50: $\mathrm{R}_{1}=\mathrm{OH}, \mathrm{R}_{2}=$ inlll $\mathrm{OH}$

51: $\mathrm{R}_{1}=\mathrm{H}, \mathrm{R}_{2}=$ ․111OH<smiles>[R]c1cc(-c2[o+]c3cc(O)cc(O)c3cc2[R20])ccc1O</smiles>

52: $\mathrm{R}_{1}=\mathrm{OH}, \mathrm{R}_{2}=$ Gal

53: $\mathrm{R}_{1}=\mathrm{OCH}_{3}, \mathrm{R}_{2}=\mathbf{G a l}$

54: $\mathrm{R}_{1}=\mathrm{OH}, \mathrm{R}_{2}=$ Ara

55: $\mathrm{R}_{1}=\mathrm{OCH}_{3}, \mathrm{R}_{2}=$ Ara

56: $\mathrm{R}_{1}=\mathrm{OH}, \mathrm{R}_{2}=$ Glc

57: $\mathrm{R}_{1}=\mathrm{OCH}_{3}, \mathrm{R}_{2}=\mathbf{G l c}$ 
Антоцианы, как и пектин, локализованы в основном в кожуре, а не в мякоти ягод. Исследование локализации антоцианов показало, что в кожице их в 6,8-10,8 раза больше, чем в мякоти; по мере созревания ягод содержание их существенно повышается: у лейкоантоцианов и катехинов заметна тенденция к увеличению в конце августа, но в осенний период их долевое участие постепенно снижается [9, 57]. В подснежной клюкве содержание антоцианов, лейкоантоцианов и катехинов несколько уменьшается. При этом установлено, что в мякоти подснежной клюквы антоцианов становится в 1,6-2,2 раза больше, а в кожице в 1,3-1,4 раза меньше, чем в соответствующих частях ягод осенней клюквы. Предполагается, что в период зимовки антоцианы перераспределяются, но все же в кожице их в 2,3-3,4 раза больше [11, 58].

В работе [24] показано, что зрелая брусника из Новосибирской и Томской областей содержит повышенное количество катехинов и антоцианов в сравнении с ягодой из других ареалов страны. Сотрудниками лаборатории лесного ресурсоведения Института леса и древесины им. В.Н. Сукачева СО АН выявлена тенденция накопления веществ, обладающих Р-витаминной активностью, в соке брусники (антоцианы - 175 240 мг\%, лейкоантоцианы и катехины - 120-190 мг\%) с юго-запада на северо-восток.

Плоды клюквы и брусники содержат и такое биологически активное соединение, как бетаин, присутствие которого ограждает организм от жирового перерождения печени и снижает содержание холестерина в крови.

В ягодах брусники и клюквы отмечается еще ряд соединений, содержащих фенольные и спиртовые гидроксильные группы. Идентифицированы представители алифатических спиртов, в том числе метаболиты жирных кислот - спиртов жирного ряда, фенола и фенольных производных, а также ароматических спиртов. Кроме того, установлено, что ягоды брусники и клюквы с разных районов севера Тюменской области в своем составе содержат альдегиды, кетоны, а также ароматообразующие и терпеновые соединения (табл. 3) [16-20].

Каждое из приведенных в таблице 3 соединений, безусловно, выполняет определенную роль в жизнеобеспечении брусники и клюквы. Например, высокомолекулярные спирты (цетиловый, эйкозанол, гексадец-9-ен-1-ола, олеиновый, октадека-9,12-диен-1-ол) входят в состав воскового налета ягод, который содержится в кутикулярном слое и покрывает клетки эпидермиса [59]. Соединения, содержащие фенольные гидроксильные группы, скорее всего, предотвращают перекисное окисление липидов и повышают устойчивость растения к неблагоприятным факторам окружающей среды [60]. Альдегиды и кетоны, предшественники более сложных соединений - карбоновых кислот, флавоноидов. Моно, ди- и сесквитерпены лежат на биосинтетических путях к три- и тетратерпенам (стеролы - кампестерин и ситостерин). Предполагается, что терпеноидные соединения в составе эфирных масел, прежде всего, выполняют в организме растений защитную функцию, защищая растения от болезней, вредителей, излишнего испарения и солнечной радиации, предохраняют их от колебания температур, затягивают раны. В ценозе данные соединения могут выполнять аллелопатическую роль во взаимоотношениях растений [61].

Стоит рассмотреть и другой класс очень важных соединений в ягодах брусники и клюквы - это витамины. Витамины являются в комплексе с белками биологическими катализаторами химических реакций или реагентами фотохимических процессов, протекающих в клетках. Они присутствуют в небольших количествах в растениях и обеспечивают нормальное протекание биохимических и физиологических процессов путем участия в регуляции обмена целостного организма [62].

Одним из наиболее изученных витаминов ягод брусники и клюквы является аскорбиновая кислота (витамин С) (табл. 4). Его содержание в разных источниках колеблется от 10,0 до 76,8 мг на 100 г свежих ягод клюквы $[6,38,47,58]$. В бруснике этот показатель ниже - от 8,0 до 30,0 мг\%. В процессе созревания происходит увеличение количества витамина $\mathrm{C}$, максимум которого наблюдается в бурой степени зрелости (полусозревшая ягода), при дальнейшем созревании оно снижается, что отмечается у некоторых авторов $[6,38,58]$. В процессе зимовки количество аскорбиновой кислоты в ягодах клюквы значительно уменьшается; в подснежной клюкве ее содержится лишь 1,6-16,7 мг\%, что составляет 6,8-16,5\% количества в осенних ягодах [11]. Степень сохранности этого витамина зависит от условий зимы и вегетационного периода, генетических особенностей отдельных популяций и форм.

Рядом исследовательских работ установлено, что метеорологические условия оказывают большое влияние на накопление аскорбиновой кислоты в ягодах. Известно, что в дождливый холодный год в ягодах накапливается меньше витамина С. Наоборот, теплая солнечная погода с непродолжительными дождями способствует наибольшему накоплению витамина С. Влияние условий места произрастания брусники на накопление аскорбиновой кислоты менее выражено [11]. 
Таблица 3. Другие идентифицированные соединения ягод брусники и клюквы

\begin{tabular}{|c|c|c|}
\hline \multirow{2}{*}{ Компонент } & \multicolumn{2}{|c|}{ Концентрация, мг на 100 г свежих ягод } \\
\hline & Vaccinium vitis-idaea $L$. & Oxycoccus palustris \\
\hline \multicolumn{3}{|c|}{ Соединения, содержашие фенольные и спиртовые гидроксильные группь } \\
\hline 2-этилгексан-1-ол & $4,5-6,0$ & $3,2-10,0$ \\
\hline Цетиловый спирт & $26,2-39,9$ & $4,3-23,6$ \\
\hline Эйкозанол & $7,7-10,6$ & $24,2-25,1$ \\
\hline Гексадец-9-ен-1-ол & $37,2-42,6$ & $8,7-17,5$ \\
\hline Олеиновый спирт & $36,7-49,6$ & $4,6-35,0$ \\
\hline Октадека-9,12-диен-1-ол & $11,8-18,6$ & $5,8-13,3$ \\
\hline Фенол & следы & $1,1-3,3$ \\
\hline 2,6-ди-трет-бутил-4-метилфенол (ионол) & $1,8-6,9$ & $0,4-4,2$ \\
\hline 2,4,6-трис(1,1-диметилэтил)фенол & $1,1-2,0$ & $1,8-2,1$ \\
\hline 4-(1,1,3,3-тетраметилбутил)фенол & $1,6-3,4$ & $1,2-2,4$ \\
\hline 2-метокси-4-винилфенол (4-винилгваякол) & $0,4-2,4$ & $0,1-0,5$ \\
\hline$n$-Кумаровый спирт & следы & 0,6 \\
\hline Бензиловый спирт & $12,2-18,6$ & $7,2-22,4$ \\
\hline Фенилэтиловый спирт & $0,2-0,4$ & 0,2 \\
\hline 3-фенил-н-пропанол & $0,7-2,6$ & не обнаружен \\
\hline 6-фенил-н-гексанол & следы & $0,3-1,6$ \\
\hline$\alpha, \alpha$-диметилфенилметанол & $2,5-6,5$ & $0,5-3,5$ \\
\hline 2-этилгексан-1-ол & $4,5-6,0$ & $3,2-10,0$ \\
\hline \multicolumn{3}{|l|}{ Альдегиды и кетонь } \\
\hline Гекс-3-ен-2-он & $0,1-0,7$ & $0,2-0,3$ \\
\hline Октаналь & $0,4-0,6$ & $0,5-1,0$ \\
\hline Нонаналь & $1,3-1,7$ & $0,1-0,6$ \\
\hline Деканаль & $4,8-5,7$ & $0,1-0,3$ \\
\hline Стеаральдегид & следы & следы \\
\hline Октадец-9-еналь & $3,3-5,6$ & $1,1-4,7$ \\
\hline Ацетофенон & $1,6-1,7$ & $1,8-4,2$ \\
\hline Бензофенон & $0,8-1,5$ & $1,0-2,7$ \\
\hline Бензальдегид & $1,6-3,5$ & $0,3-1,1$ \\
\hline Салициловый альдегид & следы & следы \\
\hline Ванилин & $0,8-3,2$ & $1,9-6,2$ \\
\hline Коричный альдегид & $0,3-1,1$ & $0,3-1,2$ \\
\hline 5-фенилпент-2-еналь & следы & $0,4-6,3$ \\
\hline \multicolumn{3}{|l|}{ Терпеновые соединения } \\
\hline 3,7-диметилокта-1,3,6-триен ( $\beta$-оцимен) & следы & следы \\
\hline 1-метил-4-изопропенилциклогекс-1-ен (D-Лимонен)* & $0,5-1,8$ & $1,8-3,7$ \\
\hline 1-метил-1-(1-метилэтил)фенил (камфоген) & 0,04 & 0,4 \\
\hline 5-метил-2-(1-метилэтил)-циклогексанол (ментол) & $0,1-0,2$ & 0,05 \\
\hline $\begin{array}{l}\alpha, \alpha-4-\text {-риметилциклогекс-3-ен-1-метанол } \\
(\alpha-\text {-терпинеол)* }\end{array}$ & $0,2-0,7$ & $0,2-0,9$ \\
\hline 1,8-эпокси-п-ментан (эвкалиптол или 1,8-цинеол)* & 0,6 & $0,1-0,4$ \\
\hline 1,7,7-триметилбицикло-[2,2,1]-гептан-2-он (камфора)* & $0,4-1,4$ & $1,0-3,3$ \\
\hline 3,7,11-триметилдодека-1,3,6,10-тетраен ( $\alpha$-фарнезен) & 0,05 & 0,3 \\
\hline 3,7,11-триметилдодека-2,6,10-триен-1-ол (фарнезол) & $0,6-2,0$ & $0,1-0,9$ \\
\hline$\alpha$-бергамотол & следы & следы \\
\hline 2,6,10,15,19,23-гексаметилтетракоза-2,6,10,14,18,22-гексаен (сквален) & $2,0-2,3$ & $1,9-2,9$ \\
\hline Кампестерин (кампестерол) & $4,8-7,8$ & $2,9-5,4$ \\
\hline Ситостерин (ситостерол) & $1,1-2,4$ & $0,3-1,0$ \\
\hline 1,1,3-триметилциклогексан (циклогераниолан) & $0,3-0,6$ & 0,2 \\
\hline 4-аллил-2-метоксифенол (эвгенол) & 0,1 & 0,05 \\
\hline$n$-Метоксипропенилбензол (анетол) & $0,4-0,6$ & $0,05-0,4$ \\
\hline 3-бутен-2-он, 4-(2,6,6-триметил-1-циклогексен-1-ил) ( $\beta$-ионон) & $0,6-1,9$ & $0,5-0,9$ \\
\hline Едулан I & $0,3-0,5$ & $0,1-0,5$ \\
\hline
\end{tabular}


Таблица 4. Состав витаминов в спелых ягодах брусники и клюквы, мг\%

\begin{tabular}{l|c|c|c}
\hline \multirow{1}{*}{ Компонент } & \multirow{2}{*}{ Vaccinium vitis-idaea L. } & \multicolumn{2}{c}{ Oxycoccus } \\
\cline { 3 - 4 } & & palustris (осенняя) & macrocarpon \\
\hline Аскорбиновая кислота & $8,0-30,0[12,40,65]$ & $10,0-76,8[11]$ & $13[82]$ \\
Провитамин А & $0,05-0,10[1,8]$ & до $0,64[11]$ & - \\
Витамин Е & $4,31-4,93[65]$ & - & - \\
Каротин & - & - & $0,022[82]$ \\
Тиамин $\left(\mathrm{B}_{1}\right)$ & $0,19-0,21[65]$ & $0,236-0,64[6,11]$ & $0,0135-0,030[11,82]$ \\
Рибофлавин $\left(\mathrm{B}_{2}\right)$ & $0,55-0,85[65]$ & $0,31[11]$ & $0,003-0,020[11,82]$ \\
Пантотеновая кислота $\left(\mathrm{B}_{3}\right)$ & $1,40-1,78[65]$ & - & $0,025[11]$ \\
$\mathrm{B}_{4}$ & $5,72-6,23[65]$ & - & - \\
Пиридоксин (В $\left(\mathrm{B}_{6}\right)$ & $0,21-1,45[65]$ & - & $0,010[11]$ \\
Фолиевая кислота $\left(\mathrm{B}_{9}\right)$ & $1,80-1,95[65]$ & - & - \\
Витамина группы В & $0,018-0,030[1,8,40]$ & - & - \\
Никотиновая кислота $($ РР) & $1,11-1,26[65]$ & $0,100[11]$ & $0,033[11]$ \\
\hline
\end{tabular}

Примечание: 1) «-»- нет данных о количественном содержании; 2) в квадратных скобках приведены литературные ссылки; 3) концентрации веществ приведены на сырую массу ягод.

Наблюдается вариация концентрации аскорбиновой кислоты в ягодах клюквы болотной в зависимости от места произрастания. Так, ягоды из сосняка сфагнового содержат аскорбиновой кислоты в количестве 15,84 мг\%, а ягоды из сосняка осоково-сфагнового чуть выше - 22,08 мг\%. Обнаружена тенденция к увеличению витамина С в районах массового распространения клюквы и снижение его к границам ареала [11].

Кроме витамина С в ягодах клюквы содержатся тиамин (витамин $\mathrm{B}_{1}-0,236-0,64$ мг\%), рибофлавин $\left(\mathrm{B}_{2}-\right.$ до 0,31 мг\%), пиридоксин $\left(\mathrm{B}_{6}\right)$, фолиевая кислота $\left(\mathrm{B}_{9}\right)$, никотиновая кислота (витамин $\mathrm{PP}-0,01$ мг\%), каротин (провитамин А от 0,094-0,236 до 0,64 мг\%) [6, 11]. В последнее время показана ценность клюквы как важного источника филлохинона (витамина $\mathrm{K}_{1}$ ), дефицит которого влечет за собой нарушение процессов образования протромбина крови. По содержанию филлохинона клюква не уступает таким хорошо изученным его источникам, как капуста, земляника и др. Его доля в ягодах клюквы составляет 0,8-1,0 мг\% [63]. Витамин $K_{1}$ присутствует и в плодах брусники. Кроме того, в бруснике найдены в небольших количествах витамины группы В (до 0,03 мг\%), витамин Е (1,0 мг\%), провитамин А $(0,05-0,10$ мг\%) [1, 8]. По содержанию каротина эта ягода превосходит остальные ягодные кустарнички, а также такие хорошо известные плоды, как лимоны, груши, виноград и чернику.

Белковых веществ в ягодах брусники и клюквы сравнительно мало (200-1240 мг\%) [40, 43, 64, 65], поэтому азотистые вещества растительного сырья мало привлекают исследователей. Азотсодержащие соединения в пересчете на общий азот присутствуют в бруснике и клюкве также в сравнительно небольшом количестве $(450-770$ мг\%, 250-710 мг\%) [11, 12]. Количество азота в зеленых или начинающих созревать ягодах брусники в 2,0-2,5 раза больше, чем в созревших [12]. В клюкве идентифицировано 17 аминокислот. Незаменимые аминокислоты составляют лишь $35,1 \%$ от их общей суммы. В группе свободных аминокислот регистрируются: лизин - 3,3-4,0, гистидин - 3,6, аргинин - 1,9-9,2, серин + аспарагиновая кислота - 7,1-13,4, глицин - 1,1, $\alpha$-аланин - 1,0-3,8, валин - 1,9, $\alpha$-аминомасляная кислота - 1,4-3,2 мг\% сырого вещества $[11,46]$.

Биохимическую характеристику плодов брусники и клюквы дополняет разнообразный минеральный состав с суммарным содержанием: $0,26-0,66 \%$ и $0,19-0,28 \%$ соответственно [1, 6-12, 53, 65, 66]. Больше всего их в семенах $(10,3 \%)$, значительно меньше в - кожице $(1,26 \%)$ и еще меньше в мякоти $(0,2 \%)$. Сравнительные данные о содержании минеральных веществ в ягодах клюквы и брусники приведены в таблице 5.

Из макроэлементов в бруснике и клюкве преобладает калий (730 и 685-1160 мг на кг свежих ягод соответственно), входящий в состав водо- и спирторастворимых солей. Содержание натрия в зрелых плодах брусники и клюквы колеблется в интервалах 70-170 и 110-190 мг/кг сырой массы соответственно, кальция - 94,6-400 и 142-800 мг/кг, магния - 22,4-70 и 21,9-80 мг/кг, фосфора - 44,5-160 и 148,7-314 мг/кг [9, 11, 12, 20, 65, 67-69]. В ягодах брусники и клюквы содержится йод, барий, бор, кобальт, никель, олово, свинец, серебро, титан, хром, цинк, алюминий. Многие элементы входят в состав разнообразных биологически активных соединений и играют важную роль в жизнедеятельности человека.

Авторами отмечается, что количество зольных веществ в плодах брусники по мере созревания уменьшается в 1,5-2 раза. Данных о динамике содержания отдельных элементов в ягодах брусники и клюквы очень мало. Установлено, что содержание натрия в ягодах бруснике по мере их созревания увеличивается, хотя в отдельные годы эта закономерность не всегда сохранялась. Концентрация марганца в зеленой 
и зрелой бруснике варьирует незначительно [12]. По мере созревания ягод клюквы некоторых элементов, например цинка, меди, бария, свинца становится меньше, других - олова и кальция - больше, а доля железа, фосфора и прочих элементов остается примерно на одном уровне. По данным А.Ф. Черкасова [11], содержание азота, фосфора и калия в ягодах клюквы меньше, чем в завязи. В подснежных ягодах клюквы некоторые элементы (кальций, фосфор, медь, молибден, олово, хром) содержатся в меньшем количестве, чем в осенних, другие (калий, вольфрам, магний, никель, свинец, серебро, стронций) - почти не изменяются, а третьи (барий, титан, цинк) - в большем. Автором [70] приводятся данные о минеральном составе ягод клюквы в зависимости от места произрастания. Содержание азота, фосфора и калия в ягодах из сосняка сфагнового несколько меньше, чем из сосняка осоково-сфагнового.

Таблица 5. Содержание минеральных элементов в спелых ягодах брусники и клюквы, мг/кг

\begin{tabular}{|c|c|c|c|}
\hline \multirow{2}{*}{ Элемент } & \multirow{2}{*}{ Брусника обыкновенная } & \multicolumn{2}{|c|}{ Клюква } \\
\hline & & болотная (осенняя) & крупноплодная \\
\hline Калий & 730 & 685 & 530 \\
\hline Натрий & $70-170$ & $110-190$ & 20 \\
\hline Кальций & $94,2-400$ & $142-800$ & 130 \\
\hline Магний & $22,4-70$ & $21,9-80$ & - \\
\hline Фосфор & $44,5-160$ & $148,7-314$ & 80 \\
\hline Железо & $11,17-190$ & $11,35-110$ & 4 \\
\hline Марганец & $83-140$ & $9,14-35$ & 6 \\
\hline Медь & 20 & $0,91-26,0$ & 4 \\
\hline Цинк & 24 & 0,029-60 & - \\
\hline Свинец & 0,108 & $0,031-0,054$ & - \\
\hline Никель & 0,065 & 0,029 & - \\
\hline Кобальт & следы & следы & - \\
\hline Хром & 0,025 & 0,039 & - \\
\hline Серебро & 0,016 & 0,001 & - \\
\hline Барий & 1,505 & $0,0014-0,0910$ & - \\
\hline Бор & - & следы & - \\
\hline Молибден & 0,02 & 0,095 & - \\
\hline Олово & 0,055 & 0,096 & - \\
\hline Стронций & 1,118 & $0,00083-0,650$ & - \\
\hline Титан & 0,245 & 0,033 & - \\
\hline Вольфрам & 0,053 & 0,012 & - \\
\hline Йод & - & 0,159 & 0,05 \\
\hline Кремний & 5,8 & $0,024-40$ & - \\
\hline Алюминий & 6,4 & $0,911-30$ & - \\
\hline
\end{tabular}

Примечание: 1) «-» - нет данных о количественном содержании; 2) концентрации веществ приведены на сырую массу ягод.

Из некоторых работ $[7,27]$ по исследованию химического состава ягод брусники и клюквы известно, что кожица, мякоть и семена содержат одни и те же элементы, но в разных количествах. Например, основное количество фосфора, марганца, меди и цинка сконцентрировано в семенах. Азота в семенах содержится $75 \%$ от всего его количества в ягоде, а почти все (95\%) железо находится в мякоти. Мякоть брусники и клюквы наиболее бедна другими минеральными элементами (кальций, натрий, магний, бор, барий), в большей степени они содержатся в семенах и кожице, а серебро преобладает в кожице ягод.

Таким образом, в настоящее время продолжаются исследования по изучению химического состава дикорастущих ягод брусники и клюквы с целью поиска и установления структуры новых соединений, обладающих терапевтическими свойствами. Поскольку именно физиологически активные компоненты, входящие в биокомплекс, обуславливают наличие тех или иных полезных свойств, как пищевых, так и лечебно-профилактических.

\section{Биологическая активность компонентного состава ягод брусники и клюквы}

Широкое использование ягод брусники и клюквы в народной медицине обусловлено наличием в них биологически активных компонентов, которые обладают антимикробными, гипотензивными, гипохолестеринемическими, цитотоксическими, антиканцерогенными, противовоспалительными, иммуностимулирующими и другими важными свойствами $[52,71]$. В настоящее время биологическая ценность ягод брус- 
ники и клюквы признается не только в народной медицине, но и на уровне официальной. Из огромного списка растений настои и морсы на основе брусники и клюквы врачами всего мира рекомендованы для профилактики ОРВИ, гриппа, мочеполовых инфекций и повышении иммунитета [71]. Весьма большие возможности применения в медицине имеют эти «ценные» ягоды благодаря наличию кислот, фенольных соединений, витаминов, минеральных веществ и других биологически активных соединений.

Витамин С, содержащийся в бруснике и клюкве, является общепризнанным антиоксидантом, значение которого для организма сложно переоценить. Аскорбиновая кислота принимает участие в непрерывно происходящих в живой клетке окислительно-восстановительных процессах, и ее рассматривают как мощный стимулирующий фактор для укрепления иммунной системы, повышающий устойчивость организма к агрессивному воздействию окружающей среды. Витамин С и $\beta$-каротин проявляют антирадикальную активность по отношению к гидроксильному радикалу $[72,73]$.

Фруктовые кислоты благоприятно влияют на жировой обмен и активизируют деятельность пищеварительного тракта. Они не повышают кислотную нагрузку на организм человека, поскольку в процессе обмена веществ быстро окисляются [57, 72].

Благодаря наличию фенолокислот (бензойной, коричных, хлорогеновой), ягоды брусники и клюквы обладают бактерицидными и антибактериальными свойствами. Кроме того, бензойная кислота - это природный антиоксидант. Существенна ее роль в укреплении клеток мембран в организме. Исследование антимикробного действия сока брусники и клюквы осенней и подснежной показало, что достаточной для прекращения роста грибов рода Candida была концентрация брусничного сока $6,66 \%$, сока осенней и подснежной клюквы - 5,33\% [21, 74-76]. В опытах на белых мышах установлено, что сок брусники полностью ликвидирует инвазию трихомонад и лямблий, показаны антимикробные свойства брусники и клюквы по отношению к Staphylococcus Pyogenus aureus, Proteus vulgaris, Salmonella Enteritidis, Salmonella Typhimurium, Listeria monocytogenes, Pseudomonas Aeruginosa [1, 77]. Известно, что не только свежевыжатый сок обладает антимикробными свойствами, но и сок, хранившийся в течение длительного времени (до 25-20 недель). Автоклавированный сок, а также сок замороженных ягод дал аналогичные результаты [76-78].

Учеными из Массачусетского университета проведен ряд исследований в отношении фармакологической активности сока крупноплодной клюквы, в результате которых установлено, что после употребления сока содержащиеся в нем флавоноиды (эпикатехин, катехин, кверцетин, мирицетин), фенольные (n-кумаровая, феруловая, кофейная, синаповая) и бензойные кислоты (бензойная, o-гидроксибензойная, м-гидроксибензойная, $n$-гидроксибензойная, 2,3-дигидроксибензойная, коричная) через некоторое время (45 и 270 мин) обнаруживаются в плазме крови человека. При этом концентрация веществ через 270 мин больше, чем через 45 мин [79]. В работе [80] отмечено снижение риска заболевания раком желудка при ежедневном употреблении ягод клюквы. Такой эффект обусловлен совместным действием фенольных кислот и антоцианов на подавление жизнедеятельности Helicobacter pylori.

Тритерпеновые кислоты - урсоловая и олеаноловая, преимущественно содержащиеся в кожице ягод, обладают выраженной биологической активностью в разнообразных медико-биологических тестах. Известно гиполипидемическое и противосклеротическое действие урсоловой и олеаноловой кислот. Выявлено, что урсоловая кислота снижает уровень холестерина и липопротеидов, а также противораковое действие урсоловой и олеаноловой кислот. Урсоловая кислота по своему действию близка к гормону надпочечников (дезоксикортикостерону), в связи с чем брусника и клюква оказывают позитивное действие при лечении болезни Адиссона. Кроме того, урсоловая и олеаноловая кислоты проявляют противогрибковую и антимикробную активность. Благодаря наличию этих кислот брусника и клюква обладают противовоспалительным и ранозаживляющим эффектом [21, 34].

Особую ценность представляют фенольные соединения, обладающие капилляроукрепляющими, противовоспалительными, антисклеротическими и антиканцерогенными свойствами. По антиоксидантной активности эти соединения в десятки раз превосходят витамины С, Е и каротиноиды [81]. Антиоксидантная активность фенольных соединений объясняется тем, что они связывают ионы тяжелых металлов в устойчивые комплексы, тем самым лишая последние каталитического действия, а также служат акцепторами образующихся при аутокислении свободных радикалов, то есть гасят свободнорадикальные процессы.

В ягодах в основном находятся фенолы с двумя ароматическими кольцами и полимерные фенольные соединения - полифенолы [51]. К фенольным соединениям с двумя фенольными кольцами относятся такие вещества с высокой биологической активностью как флавонолы, флавоны, катехины, антоцианидины, лейкоантоцианидины. По литературным данным [81-83], лейкоантоцианы обладают противоопухолевым действи- 
ем. Канадские ученые провели ряд испытаний, в ходе которых выяснили возможность применения клюквенного экстракта или сока как функциональных продуктов в укреплении здоровья и даже в профилактике или лечении рака толстой кишки [84]. Установлено, что проантоцианидины, содержащиеся в клюквенном соке, препятствует образованию зубного камня, а также замедляют прикрепление бактерий типа Eccoli к стенкам мочевыводящих путей и предотвращает воспаления в этих органах [79, 85-90]. В опытах на добровольцах установлено, что ежедневное употребление клюквенного сока (125 мл) в течение 24 недель значительно предотвращает рецидивы инфекций мочевыводящих путей [91]. Катехины обладают наиболее высокой Р-витаминной активностью по сравнению с другими группами флавоноидных соединений. Они усиливают эффект рентгенооблучения при лечении опухолей и повышают сопротивляемость организма к действию рентгеновских лучей. Кверцетин, рутин и другие флавонолы оказывают антиоксидантное действие [21]. Американские ученые из Оклахомы в своей работе показали, что прием клюквенного сока двух стаканов в день положительно влияет на снижение окисления липидов и повышение антиоксидантной способности плазмы у женщин с метаболическим синдромом [92]. Ряд американских исследователей также отмечают эффективность брусничного и клюквенного сока в снижении артериального давления, риска сердечных заболеваний и окислительного стресса при ежедневном его употреблении [93-98]. Такое действие сока ягод брусники и клюквы обусловлено наличием большого количества полифенолов в них.

Установлено, что в свежевыжатых соках ягод брусники и клюквы содержатся вещества, способные улавливать три типа кислородных радикалов (пероксид радикал, гидроксил радикал и пероксинитрит). При этом наибольшей активностью обладают антоцианы $[12,99]$. Авторы $[47,53,55]$ отмечают зависимость антирадикальной активности от содержания фенольных, в том числе антоциановых веществ. Чем больше концентрация антоцианов в плоде клюквы крупноплодной, тем выше антиоксидантная активность продукта. Отмечается, что антиокислительная активность цианидин-3-глюкозида на $75 \%$ больше, чем цианидин3-галактозида, и на 90\% больше, чем антиокислительная активность пеонидин-3-глюкозид [56].

Характерным представителем гидролизуемых дубильных веществ является танин. Исследователи, проверив лечебные свойства клюквенного сока, пришли к выводу, что основными веществами, действующими подавляюще на болезнетворные микроорганизмы в мочевом пузыре и почках, являются танины [82]. Кроме того, вещества, содержащиеся в клюквенном и брусничном соке, повышают содержание в организме липопротеина холестерина и антиоксидантов, необходимых для нормального функционирования сердечно-сосудистой системы [100, 101].

Известен лечебный эффект клюквенного сока, применяемого вместе с антибиотиками при послеродовых осложнениях и при гинекологических воспалительных заболеваниях. Это свойство клюквы, очевидно, объясняется наличием в ней значительного количества лимонной кислоты, которая усиливает всасывание антибиотиков [21]. Известно, что напитки из брусники и клюквы также обладают бактерицидным действием и усиливают лечебную активность антибактериальных препаратов $[47,102]$. Брусничный и клюквенный морсы принимают при простудных заболеваниях. Сокосодержащие напитки оказывают антивирусное, противовоспалительное, жаропонижающее и общеукрепляющее действие $[8,21,98,103]$.

В состав ягод брусники и клюквы входят пектиновые вещества. Пектиновые вещества не усваиваются организмом, однако способствуют осуществлению многих положительных функций: выводят из организма токсичные металлы и радионуклиды, подавляют развитие гнилостных бактерий, препятствуют избыточному брожению углеводов, способствуют связыванию эндогенных и экзогенных токсинов. Поэтому ягоды и продукты на их основе оказывают позитивное действие при лечении желудочно-кишечного тракта [21, 82, 83].

Минеральные вещества с физиологической точки зрения являются не менее важными составными частями ягод. Они связаны с ферментной системой клетки и обеспечивают постоянство осмотического давления в тканях живого организма. Соли органических кислот (яблочной, лимонной и др.) характеризуются щелочной реакцией. Они нейтрализуют кислые продукты, образующиеся в организме в результате обмена веществ, и этим содействуют поддержанию активной реакции тканей и жидкостей. Железо, медь, кобальт и марганец участвуют в процессах кроветворения. Магний имеет большое значение для работы сердца и состояния всей мышечной системы. Фосфор и кальций являются главнейшими составными частями костной системы. Соли калия обеспечивают требуемый уровень содержания воды в тканях, натрий регулирует водный обмен, хлор необходим для образования соляной кислоты желудочного сока. Йод способствует работе щитовидной железы [83]. 
Невозможно отдельно взятому компоненту приписать определенную биологическую активность ягод брусники и клюквы. Биологическую ценность ягод, как брусники, так и клюквы, обусловливает весь комплекс веществ в целом. Кроме того, в растениях присутствуют вещества, действующие во взаимоусиливающем направлении. Например, одновременное присутствие в ягодах витаминов Р и С обеспечивает условия благоприятного проявления в организме биологического действия этих веществ [83].

\section{Практическое использование ягод и перспективные методы безотходного произвоства}

В настоящее время на основе ягод брусники и клюквы производятся и активно продаются как у нас в стране, так и за рубежом настойки («Клюква», «Брусника» фирмы ГК «КиН», Москва), сиропы («Брусника с клюквой», ООО «Вивако», Нижний Новгород), экстракты и порошки («Витаморс имунно», ЗАО «Фармакор», Санкт-Петербург), биологически активные добавки («Брусника с клюквой», ЗАО «Биофит», Нижний Новгород; «Bio Cran», SupHerb, Израиль; «Cranberry», NOW Foods, США), лечебная косметика («Фитокомплекс-Новель», Новель Криэшен, Израиль), а также фармакологические препараты («Urisan», Hankintatukku Оу, Финляндия).

В пищевой промышленности предложены технология получения антоцианового пигмента из ягод клюквы методом лиофильной сушки и дальнейшее его использование для окраски суфле [104, 105]. Ученые из Кемеровского технологического института пищевой промышленности достаточно активно занимаются вопросами переработки ягод брусники и клюквы [106]. В своих статьях они приводят результаты исследования пищевой ценности диетических джемов, приготовленных на основе ягод брусники и клюквы, с пониженным гликемическим индексом. Разработана технология подготовки дикорастущего сырья для получения гомогенной системы и концентрата дикорастущего сырья, имеющих однородную структуру и высокое содержание биологически активных веществ, для последующей переработки при производстве функциональных молочных продуктов [107].

В работе [108] предложены новые рецептуры соусов и дрессингов на основе пюре из ягод клюквы. Авторами отмечается, что соусы и дрессинги на основе пектинсодержащего сырья обогащают блюда биологически активными веществами и характеризуются низким содержанием сахаров, благодаря чему их можно включать в рацион людям с повышенным содержанием сахара в крови. Разработаны технологические схемы получения паст из мороженых выжимок ягод брусники и клюквы, а также порошки на их основе [109]. Описан метод получения сублимированного порошка из клюквы и в работе исследователей из Пятигорска [110].

Исследователями [111] предложен метод сушки ягод как способ консервирования данного сырья для его сохранности и обеспечения бесперебойной работы предприятия в течение года.

Безалкогольные напитки учеными многих стран, в том числе и России, рассматриваются как оптимальная форма пищевых продуктов, используемых для удовлетворения потребности организма человека в биологически активных веществах (БАВ). На основе ягод брусники и клюквы предложен широкий ассортимент напитков (настои, морсы, квас) и технологий настаивания для извлечения как можно большего количества биологически активных веществ, в том числе с применением ферментных препаратов [112-116]. Северокавказским зональным научно-исследовательским институтом садоводства и виноградарства совместно с научным центром виноделия разработана рецептура производства вина из клюквы $[117,118]$. В единичных работах встречаются предложения по переработке отходов соковых производств предприятий пищевой и перерабатывающей промышленности АПК. В своей работе авторы [69] описывают способы получения мучных кондитерских изделий, кексов пониженной калорийности и порошков из выжимок ягод брусники и клюквы. В работе [119] приведен способ извлечения пектина из ягод, который в дальнейшем целесообразно использовать в медицинской промышленности.

Несомненно, что каждый из предложенных продуктов, полученный на основе ягод брусники и клюквы, благодаря наличию биологически активных соединений, проявляет пищевую и биологическую ценность. Данный факт очень важен для поддержания здоровья нации, особенно в настоящее время, когда антропогенная нагрузка возросла в разы.

Несмотря на достаточно глубокую степень изученности химического состава ягод брусники и клюквы, всестороннего исследования биологической и фармацевтической активности их биокомплексов и разнообразных методов переработки сырья, остается нерешенным вопрос по комплексной переработке ягод брусники и клюквы. Чтобы найти возможные пути решения проблемы безотходного производства и массового внедрения новых видов пищевой продукции на основе ягод брусники и клюквы, необходимо продолжать исследования в данном направлении. 


\section{Сиисок литературы}

1. Губанов И.А. Дикорастущие полезные растения. М., 1987. 158 с.

2. Зуев Д.П. Дары русского леса. М., 1977. 239 с.

3. Рабинович А.М. Лекарственные растения России. М., 2001. 319 с.

4. Югория: энциклопедия Ханты-Мансийского автономного округа. Ханты-Мансийск: НИИ региональных энциклопедий ТюмГУ, 2000. 400 с.

5. Новиков В.С., Губанов И.А. Популярный атлас-определитель. Дикорастущие растения. 5-е изд., стереотип. M., 2008. $415 \mathrm{c}$.

6. Баранова И.И. К состоянию изученности пищевой и лекарственной ценности некоторых дикорастущих ягод Карелии // Комплексные исследования растительности болот Карелии. Петрозаводск, 1982. С. 156-166.

7. Баранова И.И. Химический состав и лекарственное значение ягод клюквы Карелии // Ресурсы ягодных и лекарственных растений и методы их изучения. Петрозаводск, 1975. С. 88-93.

8. Зайцева А.Н., Сорокина Е.Ю., Аксюк И.Н., Левин Л.Г. Ягоды брусники: химический состав, пищевые и целебные свойства // Вопросы питания. 1997. №2. С. 38-40.

9. Брусничные в СССР: Ресурсы, интропродукция, селекция. Новосибирск, 1990. 320 с.

10. Сорокопуд А.Ф., Мустафина А.С., Суменков М.В. Перспективы использования экстрактов клюквы, брусники и черники в пищевой промышленности // Пищевая промышленность. 2001. №9. С. 32-33.

11. Черкасов А.Ф., Буткус В.Ф., Горбунов А.Б. Клюква. М., 1981. 216 с.

12. Юдина В.Ф., Колупаева К.Г., Белоногова Т.В., Муратов Ю.М. Брусника. М., 1986. 80 с.

13. Гудвин Т., Мерсер Э., Введение в биохимию растений: в 2 т. М., 1986. Т. 1. 393 с.; Т. 2. 312 с.

14. Кретович В.Л. Биохимия растений. М., 1980. 445 с.

15. Скрипников Ю.Г. Производство плодово-ягодных вин и соков. М., 1983. 256 с.

16. Лютикова М.Н., Туров Ю.П. Исследование компонентного состава ягод местной дикорастущей брусники (Vaccinium vitis-idaea L.) // Химия растительного сырья. 2011. №1. С. 145-149.

17. Lyutikova M.N., Turov Y.P. Chemical constituents from wild oxycoccus palustris fruit from north Tyumen oblast // Chemistry natural compounds. 2011. Vol. 46, N6. Pp. 848-851.

18. Лютикова М.Н., Туров Ю.П. Компонентный состав свежих, мороженых и подснежных ягод клюквы (Oxусоccus palustris) // Химия растительного сырья. 2011. №4. С. 231-237.

19. Лютикова М.Н., Туров Ю.П., Ботиров Э.Х. Применение хромато-масс-спектрометрии для определения свободных и этерифицированных жирных кислот при их совместном присутствии в растительном сырье // Вестник МИТХТ. 2013. Т. 8, №2. С. 52-57.

20. Лютикова М.Н. Изучение состава биологически активных компонентов дикорастущих ягод Vaccinium vitisidaea L. и Oxycoccus palustris в зависимости от степени их зрелости и условий хранения: автореф. дисс. ... канд. хим. наук. Черноголовка, 2013. 26 с.

21. Липкан Г.Н. Применение плодово-ягодных растений в медицине. Киев, 1988. 152 с.

22. Pehkonen T., Koskimäki J., Riihinen K., Pirttilä A.M., Hohtola A., Jaakola L., Tolvanen A. Artificial infection of Vaccinium vitis-idaea L. and defence responses to Exobasidium species // Physiological and Molecular Plant Pathology. 2008. Vol. 72. Pp. 146-150.

23. Mason G. F. The Occurrence of Benzoic Acid Naturally in Cranberries // J. Am. Chem. Soc. 1905. Vol. 27 , N5. Рp. 613-614.

24. Губина М.Д. Химический состав, хранение и использование дикорастущих плодов черники и брусники, произрастающих в Западной Сибири: автореф. дисс. ... канд. техн. наук. Ленинград, 1983. 21 с.

25. Zuo Y., Wang Ch., Zhan J. Separation, characterization, and quantitation of benzoic acid phenolic antioxidants in American fruit by GC-MS // J. Agric. Food Chem. 2001. Vol. 50. Pp. 3789-3794.

26. Богданова Г.А., Муратов Ю.М. Брусника в лесах Сибири. М., 1978. 116 с.

27. Конобеева А.Б. Хозяйственно-биологическая оценка голубики, черники, брусники и клюквы в условиях Центрально-Черноземного региона: автореф. дисс. ... канд. с.-х. наук. Мичуринск, 2002. 19 с.

28. Jankowski K., Jocelyn Pare J.R. Trace glycoside from cranberries (Vaccinium oxycoccus) // J. Nat. Prod. 1983. Vol. 46. Pp. 190-193.

29. Jensen D., Krogfelt A., Cornett C. Hydrophilic carboxylic acids and iridoid glycosides in the juice of American and European cranberries, lingonberries, and blueberrie // J. Agric. Food Chem. 2002. Vol. 50. Pp. 6871-6874.

30. Kallio H., Nieminen R., Tuomasjukka S., Hakala M. Cutin composition of five finnish berries // J. Agric. Food Chem. 2006. Vol. 54. Pp. 457-462.

31. Романова Н.К., Решетник О.А., Ефремов Ю.Я., Шарафутдинова Д.Р. Компонентный состав ягод клюквы, используемой в ликероводочном производстве // Производство спирта и ликероводочных изделий. 2004 . №1. C. 21-22.

32. Хелт Г-В. Биохимия растений. М., 2011. 290 с.

33. Козлов Л.П., Кукина Т.П. Отходы пилотной наработки урсоловой кислоты из ягодных шротов как источник БАВ // Химия растительного сырья. 2006. №1. С. 314-317.

34. Кукина Т.П., Попов С.А. Содержание и распределение урсоловой и олеаноловой кислот в плодах, жомах и шротах клюквы болотной // Химия растительного сырья. 2005. №2. С. 310-313. 
35. Murphy B.T., Mackinnon Sh.L., Yan X., Hammond G.B., Vaisberg A.J, and Neto G.C. Identification of triterpene hydroxycinnamates with in vitro antitumor activity from wholl // J. Agric. Food Chem. 2003. Vol. 51. Pp. 3541-3545.

36. Mattila P., Hellstrm J., Trrnen R. Phenolic acids in berries, fruits, and beverages // J. Agric. Food Chem. 2006. Vol. 54. Pp. 7193-7199.

37. Zheng Z., Shetty K. Solid-state bioconversion of phenolics from cranberry pomace and role of lentinus edodes $\beta$-glicosidase // J.Agric.Food Chem. 2000. Vol. 48. Pp.895-900.

38. Сенчук Г.В. Биохимические свойства и сохраняемость дикорастущих ягод Белоруссии: автореф. дисс. ... канд. техн. наук. М., 1973. 20 с.

39. Фомичева П.К., Батура Е.В. Содержание флавоноидов в ягодах клюквы, брусники, культивируемых на опытных участках Костромской области // Актуальные проблемы науки в агропромышленном комплексе. 2007. T. 2. C. 64.

40. Расщепкина Е.А., Субботина М.А., Расщепкин А.Н. Исследование химического состава брусники // Технология и продукты здорового питания. 2008. №8. С. 117-118.

41. Matsushima M., Suzuki T., Masui A., Mine T., Takagi A. Cranberry extract suppresses interleukin-8 secretion from stomach cells stimulated by Helicobacter pylori in every clinically separated strain but inhibits growth in part of the strains // J. of Functional Foods. 2013. Vol. 5. Pp. 729-735.

42. Tarascou I., Mazauric J.-P., Meudec E., Souquet J.-M., Cunningham D., Nojeim S., Cheynier V., Fulcrand H. Characterisation of genuine and derived cranberry proanthocyanidins by LC-ESI-MS Original Research Article // Food Chemistry. 2011. Vol. 128. Pp. 802-810.

43. Lee J., Finn C.E. Lingonberry (Vaccinium vitis-idaea L.) grown in the Pacific Northwest of North America: Anthocyanin and free amino acid composition // J. of Functional Foods. 2012. Vol. 4. Pp. 213-218.

44. Тутельян В.А., Батурин А.К., Мартинчик Э.А. Флавоноиды: содержание в пищевых продуктах, уровень потребления, биодоступность // Вопросы питания. 2004. №6. С.43-48.

45. Amakura Y., Umino Y., Tsuji S., Tonogai Y. Influence of jam processing on the radical scavenging activity and phenolic content in berries // J. Agric. Food Chem. 2000. Vol. 48. Pp. 6292-6297.

46. Кузнецова Н.А. Пищевая ценность соков из дикорастущих ягод клюквы и черники. М., 1975. 33 с.

47. Borowska I., Szajdek A. Antioxidant Activity of Berry Fruits and Beverages // Pol. J. Natur. Sci. 2003. N14. Pp.521-528.

48. Ek S., Kartimo H., Mattila S., Tolonen A.. Characterization of phenolic compounds from lingonberry (Vaccinium vitis-idaea) // J. Agric. Food Chem. 2006. Vol. 54. Pp. 9834-9842.

49. Wang Y., Catana F., Yang Y., Roderick R. An LC-MS method for analyzing total resveratrol in grape juice, cranberry juice, and in wine // J. Agric. Food Chem. 2002. Vol. 50, N3. Pp.431-435.

50. Hakkinen S.H., Karenlampi S.O., Heinonen I.M., Mykkanen H.M., Torronen A.R.. Content of the flavonols quercetin, myricetin, and kaempferol in 25 edible berries // J. Agric. Food Chem., 1999. Vol. 47, N6. Pp. 2274-2279.

51. Ермолаева Г.А. Сырье для сокосодержащих напитков // Пиво и напитки. 2004. №1. С.48-50.

52. Марсов Н.Г. Фитохимическое изучение и биологическая активность брусники, клюквы и черники: автореф. дис. ... канд. фарм. наук. Пермь, 2006. 24 с.

53. Prior R.L., Lazarus S.A., Cao G., Muccitelli H., Hammerstane J.F. Identification of procyanidins and anthocyanins in blueberries and cranberries using high-performance liquid chromatography/mass spectrometry // J. Agric. Food Chem. 2001. Vol. 49. Pp. 1270-1276.

54. Wang Sh.Y., Stretch A.W. Antioxidant capacity in cranberry is influenced by cultivar and storage temperature // J. Agric. Food Chem. 2001. Vol. 49. Pp. 969-974.

55. Yuan W., Zhou L., Deng G., Wang P., Creech D., Li Sh. Anthocyanins, phenolics and antioxidant capacity of Vaccinium L. in Texas, USA. // Pharmaceutical Crops. 2011. Vol. 2. Pp. 11-23.

56. Vorsa N., Polashock J., Cunningham D., Roderick R.. Genetic Inferences and Breeding Implications from Analysis of Cranberry Germplasm Anthocyanin Profiles // J. Am. Soc. Hortic. Sc. 2003. Vol. 128. Pp. 691-697.

57. Филатова И.А., Филиппова Р.Л., Колеснов А.Ю., Дьяченко М.А. Идентификации продуктов переработки ягод, содержащих экстракты выжимок // Пищевая промышленность. 2006. №1. С. 24-26.

58. Авилова С.В., Иванова С.В. Купажирование натуральных соков с использованием черники, брусники и клюквы // Известия ТСХА. Вып. 2. 2005. С. 59-67.

59. Филипцова Г.Г. Основы биохимии растений. Минск, 2004. 136 с.

60. Братус И.Н. Химия душистых веществ. М., 1992. 240 с.

61. Метлицкий Л.В., Озерецковская О.Л., Караблева Н.П. Биохимия иммунитета, покоя, старения растений. М., 1984. $264 \mathrm{c}$.

62. Семенов А.А. Очерк химии природных соединений. Новосибирск, 2000. 664 с.

63. Пилат Т.Л., Иванов А.А. Биологически активные добавки к пище (теория, производство, применение). М., 2002. $710 \mathrm{c}$.

64. Курбатова Е.И. Разработка биотехнологического процесса получения полуфабрикатов ликероводочных изделий на основе ферментативной обработки плодово-ягодного сырья: автореф. дисс. ... канд. техн. наук. М., 2005. 22 c.

65. Терентьева В.М. Биохимическая оценка высушенных ягод брусники Центральной Якутии [Оценка качества дикорастущих ягод с целью разработки технологий переработки и хранения] // Сибирский вестник сельскохозяйственной науки. 2008. №10. С. 113-116.

66. Рабинович А.М. Лекарственные растения России. М., 2001. 319 с. 
67. Кирилюк Л.И., Буганова А.А., Захарина Т.Н., Бахтина Е.А. Ягодники Ямальского региона: особенности экологии и микроэлементный состав // Лесное хозяйство. 2005. №6. С.29-30.

68. Григорюк Г.П., Старостина Е.Б., Заикина Н.В. Пищевые добавки из лесного растительного сырья // Сборник материалов II Всероссийской конференции «Химия и технология растительных веществ». Казань, 2002. C. 136.

69. Кольман О.Я., Иванова Г.В. Моделирование и оптимизация рецептур мучных кондитерских изделий функционального назначения // Вестник КрасГАУ. 2013. №4. С. 179-185.

70. Кабанова Н.И. Качественный анализ клюквы болотной // Лес, наука, молодежь. 1999. Т. 2. С. $222-224$.

71. Быков А.Т., Бова С.И., Шамко И.А. Натуральная медицина: уропротекторная роль клюквы // Медицинский журнал. 2012. №3. С. 4-7.

72. Viljakainen S., Visti A., Laakso S. Concentrations of Organic Acids and Soluble Sugars in Juices from Nordic Berries // Acta Agriculturae Scandinavica: Section B, Soil and Plant Science. 2002. Vol. 52. Pp. 101-109.

73. Dorofejeva K., Rakcejeva T., Galoburda R., Dukalska L., Kviesis J. Vitamin C content in Latvian cranberries dried in convective and microwave vacuum driers // Food Science. 2011. Vol. 1. Pp. 433-440.

74. Côté J., Caillet S., Doyon G., Dussault D., Sylvain J.-F., Lacroix M. Antimicrobial effect of cranberry juice and extracts // Food Control. 2011. Vol. 22. Pp. 1413-1418.

75. Côté J., Caillet S., Doyon G., Dussault D., Sylvain J.-F., Lacroix M. Antimicrobial effects of fractions from cranberry products on the growth of seven pathogenic bacteria // Food Control. 2012. Vol. 23. Pp. 419-428.

76. Lacombe A., Vivian C.H. Wu, Tyler S., Edwards K. Antimicrobial action of the American cranberry constituents; phenolics, anthocyanins, and organic acids, against Escherichia coli // International Journal of Food Microbiology. 2010. Vol. 139. Pp. 102-107.

77. Côté J., Caillet S., Dussault D., Sylvain J.-F., Lacroix M. Effect of juice processing on cranberry antibacterial properties // Food Research International. 2011. Vol. 44. Pp. 2922-2929.

78. Минаева В.Г. Лекарственные растения Сибири. Новосибирск, 1991. 429 с.

79. Zhang K., Zuo Y. GC-MS determination of flavonoids and phenolic and benzoic acids in human plasma after consumption of cranberry juice // J. Agric. Food Chem. 2004. Vol. 52. Pp. 222-227.

80. Matsushima M., Suzuki T., Masui A., Mine T., Takagi A. Cranberry extract suppresses interleukin-8 secretion from stomach cells stimulated by Helicobacter pylori in every clinically separated strain but inhibits growth in part of the strains // J. of Functional Foods. 2013. Vol. 5. Pp. 729-735.

81. Георгиевский В.П. Биологически активные вещества лекарственных растений. Новосибирск, 1990. 327 с.

82. Kalt W. Health functional phytochemicals of fruit // Hortic. Revs. New York, 2001. Vol. 27. Pp. 269-315.

83. Шабров А.В. Биохимические основы действия микрокомпонентов пищи. М., 2003. 184 с.

84. Vu K.D., Carlettini H., Bouvet J., Côté J., Doyon G., Sylvain J.-F., Lacroix M. Effect of different cranberry extracts and juices during cranberry juice processing on the antiproliferative activity against two colon cancer cell lines // Food Chemistry. 2012. Vol. 132. Pp. 959-967.

85. Johnson-White B., Buquo L., Zeinali M., Ligler F.S. Prevention of nonspecific bacterial cell adhesion in immunoassays by use of cranberry juice // Anal. Chem. 2006. Vol. 78. Pp. 853-857.

86. Erickson B. Research: cranberry juice prevents non specific adhesion // Anal. Chem. 2006. Vol. 78. Pp. 638.

87. Yeap Foo L., Yinrong Lu, Amy B. Howell, Nicholi Vorsa. A-Type proanthocyanidin trimers from cranberry that inhibit adherence of urapathogenic p-fimbriated Escherichia coli. // J. Nat. Prod. 2000. Vol. 63. Pp. 1225-1228.

88. Chen C.H., Ho D.R., Lin W., Ho D.R., Chang P.J., Huang Y.J. Urine post equivalent daily cranberry juice consumption may opsonize uropathogenicity of Escherichia coli Original Research Article // J. of Infection and Chemotherapy. 2013. Vol. 19. Pp. 812-817.

89. Mathison B., Kimble L., Kaspar K., Khoo C., Chew B. Consumption of cranberry beverage improved endogenous antioxidant status and protected against bacteria adhesion in healthy humans: a randomized controlled trial // Nutrition Research. In Press. Accepted Manuscript. 2014. Pp. 1-31.

90. Kim S.H., Ha U-S., Lee H.L., Sohn D.W., Lee S.-J., Kim H.W., Han H.C., Lee C.B., Cho Y.-H. Do Escherichia coli extract and cranberry exert preventive effects on chronic bacterial prostatitis? Pilot study using an animal model // J. of Infection and Chemotherapy. 2011. Vol. 17. Pp. 322-326.

91. Takahashi S., Hamasuna R., Yasuda M., Arakawa S., Tanaka K. A randomized clinical trial to evaluate the preventive effect of cranberry juice (UR65) for patients with recurrent urinary tract infection Original Research Article // J. of Infection and Chemotherapy. 2013. Vol. 19. Pp. 112-117.

92. Basu A., Betts N.M., Ortiz J., Simmons B., Wu M., Lyons T.J. Low-energy cranberry juice decreases lipid oxidation and increases plasma antioxidant capacity in women with metabolic syndrome // Nutrition Research. 2011. Vol. 31. Pp. 190-196.

93. Elberry A., Abdel-Naim A., Abdel-Sattar E., Nagy A., Mosli H., Mohamadin A., Ashour O. Cranberry (Vaccinium macrocarpon) protects against doxorubicin-induced cardiotoxicity in rats Original Research Article // Food and Chemical Toxicology. 2010. Vol. 48. Pp. 1178-1184.

94. Kowalska K., Olejnik A., Rychlik J., Grajek W. Cranberries (Oxycoccus quadripetalus) inhibit adipogenesis and lipogenesis in 3T3-L1 cells Original Research Article // Food Chemistry. 2014. Vol. 148. Pp. 246-252.

95. Artemio Z., Tulio Jr., Jablonskia J., Jacksona L., Lauren S., Changa C., Edirisinghec I. Burton-Freemanc B. Phenolic composition, antioxidant properties, and endothelial cell function of red and white cranberry fruits // Food Chemistry. 2014. Vol. 157. Pp. 540-552. 
96. Kivimäki A., Siltari A., Ehlers P., Korpela R., Vapaatalo H. Lingonberry juice negates the effects of a high salt diet on vascular function and low-grade inflammation Original Research Article // J. of Functional Foods. 2014. Vol. 7. Pp. 238-245.

97. Kivimäki A., Siltari A., Ehlers P., Korpela R., Vapaatalo H. Lingonberry juice lowers blood pressure of spontaneously hypertensive rats (SHR) // J. of Functional Foods. 2013. Vol. 5. Pp. 1432-1440.

98. Khoo C., Falk M. Polyphenols in the Prevention and Treatment of Vascular and Cardiac Disease, and Cancer // Polyphenols in Human Health and Disease. 2014. Vol. 2. Pp. 1049-1065.

99. He J., Rodriguez-Soana L.E., Giusti M.M.. Midinfrared spectroscopy for juice authentication rapid differentiation of commercial juices // J. Agric. Food Chem. 2007. Vol. 55. Pp. 4443-4452.

100. Иванова Р.И., Прида А.И. Природные антиоксиданты полифенольной природы (Антирадикальные свойства и перспективы использования) // Пищевые ингредиенты: сырье и добавки. 2004. №2. С. 76-78.

101. Kivimäki A., Siltari A., Ehlers P., Korpela R., Vapaatalo H. Lingonberry juice negates the effects of a high salt diet on vascular function and low-grade inflammation Original Research Article // J. of Functional Foods. 2014. Vol. 7. Pp. 238-245.

102. Lipson S.M., Sethi L., Cohen P., Gordon R.E., Tan I.P., Burdowski A., Stotzky G. Antiviral effects on bacteriophages and rotavirus by cranberry juice // Phytomedicine. 2007. Vol. 14. Pp. 23-30.

103. Su X., Howell A.B., D'Souza D.H. The effect of cranberry juice and cranberry proanthocyanidins on the infectivity of human enteric viral surrogates Article // Food Microbiology. 2010. Vol. 27. Pp. 535-540.

104. Мурашев С.В., Болейко Л.А., Вержук В.Г., Жестков А.С. Определение свойств и практическое применение антоцианового пигмента из ягод клюквы (Охусосcus Hill.) // Кондитерское производство. 2011. №2. С. 8-11.

105. Мурашев С.В., Жемчужникова М.Е., Вержук В.Г. Антоциановый пигмент, получаемый из растительного сырья методом сублимационной сушки // Овощи России. 2013. №4 (21). С. 50-51.

106. Киселева Т.Ф., Григорьева М.С., Золин А.Г. Диетические джемы с низким гликемическим индексом // Техника и технология пищевых производств. 2011. №1. С. 114-117.

107. Лупинская С.М. Подготовка дикорастущего сырья при получении функциональных молочных продуктов // Техника и технология пищевых производств. 2010. Т. 18, №3. С. 13-17.

108. Мацейчик И.В., Добрыдина Е.С. Разработка новых рецептур и технологий продуктов функционального назначения на основе пектинсодержащего сырья // Вестник КрасГАУ. 2009. №4. С. 208-213.

109. Кольман О.Я., Иванова Г.В. Способы консервирования вторичного сырья дикорастущих ягод брусники и клюквы // Вестник КрасГАУ. 2013. №5. С. 218-222.

110. Бутенко Л.И., Лигай Л.В. Сублимационный порошок клюквы - источник витамина С и аминокислот // Международный журнал экспериментального образования. 2011. №6. С. 82-84.

111. Кравченко С.Н., Химич А.Н. Качественная характеристика высушенных ягод клюквы как сырья для производства экстрактов // Фундаментальные исследования. 2008. №12. С. 46.

112. Сорокопуд А.Ф., Астафьева А.Н. Насыщение растворителя при переработке замороженных ягод брусники в виброэкстракторе // Техника и технология пищевых производств. 2013. №1. С. 1-5.

113. Кравченко С.Н., Попов А.М., Химич А.Н. Физиологическая ценность экстрактов, полученных из высушенных ягод и жома клюквы // Известия вузов. Пищевая технология. 2009. №2-3. С. 43-46.

114. Овсянникова Е.А., Понамарёва М.В., Потапов А.Н., Киселёва Т.Ф. Интенсификация экстракционных процессов биокаталитическим методом // Вестник КрасГАУ. 2013. №1. С. 169-173.

115. Кияшкина Л.А., Цугкиева В.Б., Датиева Б.А., Шабанова И.А. Использование сока клюквы в производстве кваса // Известия Горского государственного аграрного университета. 2013. Т. 50, №1. С. 304-307.

116. Овсянникова Е.А., Киселева Т.Ф., Потапов А.Н., Дюжев А.В. Исследование процесса экстрагирования дикорастущих ягод Сибири с использованием биокаталитических методов // Техника и технология пищевых производств. 2012. №4. С. 1-4.

117. Кушнерева Е.В., Гугучкина Т.И., Паутов Р.Ю. Выбор режима обработки мезги для приготовления вин из ягод клюквы // Альманах современной науки и образования. 2010. №7 (38). С. 81-83.

118. Гугучкина Т.И., Кушнерева Е.В., Паутов Р.Ю. Сравнительная оценка режимов переработки мезги клюквы для производства вин с высокой биологической ценностью // Плодоводство и виноградарство Юга России. 2011. №8. С. 126-133.

119. Гимаев И.Н., Романова Н.К., Решетник О.А. Влияние параметров процесса гидролиза-экстракции на выход и качество пектина из плодово-ягодного сырья // Вестник Казанского технологического университета. 2004. №1. С. 214-218. 


\section{Lyutikova M.N.*, Botirov E.Kh. THE CHEMICAL COMPOSITION AND THE PRACTICAL APPLICATION OF BERRIES CRANBERRIES AND CRANBERRY}

Surgut State University, ul. Lenina, 1, Surgut, 628412 (Russia), e-mail: m.lyutikova@mail.ru

The review discusses the current status of research in the chemical composition of forest and cultivated species of berries cranberries (Vaccinium vitis-idaea L.) and cranberry (Oxycoccus palustris, Oxycoccus macrocarpon) growing on the territory of different countries. A compara- tive analysis of the composition of berries within each species growing in different regions. Lit biological significance of the berries cranberries and cranberry, as well as their practical application in pharmaceuticals, traditional medicine and some food industries.

Keywords: Lingonberry (Vaccinium vitis-idaea L.), cranberry (Oxycoccus palustris, Oxycoccus macrocarpon), organic acids, alcohols, aldehydes, ketones, esters, terpene compounds, mineral composition.

\section{References}

1. Gubanov I.A. Dikorastushhie poleznye rastenija. [Wild useful plants.]. Moscow, 1987, 158 p. (in Russ.).

2. Zuev D.P. Dary russkogo lesa. [Gifts of Russian forests]. Moscow, 1977, 239 p. (in Russ.).

3. Rabinovich A.M. Lekarstvennye rastenija Rossii. [Herbs Russia]. Moscow, 2001, 319 p. (in Russ.).

4. Jugorija: jenciklopedija Hanty-Mansijskogo avtonomnogo okruga. [Yugoria: Encyclopedia of the Khanty-Mansi Autonomous Okrug]. Hanty-Mansijsk, 2000, 400 p. (in Russ.).

5. Novikov V.S., Gubanov I.A. Populjarnyj atlas-opredelitel'. Dikorastushhie rastenija. [A popular field guide. Wild plants]. Moscow, 2008, 415 p. (in Russ.).

6. Baranova I.I. Kompleksnye issledovanija rastitel'nosti bolot Karelii. Petrozavodsk, 1982, pp. 156-166. (in Russ.).

7. Baranova I.I. Resursy jagodnyh i lekarstvennyh rastenij i metody ih izuchenija. Petrozavodsk, 1975, pp. 88-93. (in Russ.).

8. Zajceva A.N., Sorokina E.Ju., Aksjuk I.N., Levin L.G. Voprosy pitanija, 1997, no. 2, pp. 38-40. (in Russ.).

9. Brusnichnye v SSSR: Resursy, introprodukcija, selekcija. [Cowberry in the USSR: Resources introproduktsiya, selection]. Novosibirsk, 1990, 320 p. (in Russ.).

10. Sorokopud A.F., Mustafina A.S., Sumenkov M.V. Pishhevaja promyshlennost', 2001, no. 9, pp. 32-33. (in Russ.).

11. Cherkasov A.F., Butkus V.F., Gorbunov A.B. Kljukva. [Cranberry]. Moscow, 1981, 216 p. (in Russ.).

12. Judina V.F., Kolupaeva K.G., Belonogova T.V., Muratov Ju.M. Brusnika. [Lingonberry]. Moscow, 1986, 80 p. (in Russ.).

13. Gudvin T., Merser Je. Vvedenie v biohimiju rastenij, [Introduction to Plant Biochemistry]. Moscow, 1986, vol. 1, 393 p.; vol. 2, 312 p. (in Russ.).

14. Kretovich V.L. Biohimija rastenij. [Plant Biochemistry]. Moscow, 1980, 445 p. (in Russ.).

15. Skripnikov Ju.G. Proizvodstvo plodovo-jagodnyh vin i sokov. [Production of fruit wines and juices]. Moscow, 1983, 256 p. (in Russ.).

16. Ljutikova M.N., Turov Ju.P. Himija rastitel'nogo syr'ja, 2011, no. 1, pp. 145-149. (in Russ.).

17. Lyutikova M.N., Turov Y.P. Chemistry natural compounds, 2011, vol. 46, no. 6, pp. 848-851.

18. Ljutikova M.N., Turov Ju.P. Himija rastitel'nogo syr'ja, 2011, no. 4, pp. 231-237. (in Russ.).

19. Ljutikova M.N., Turov Ju.P., Botirov Je.H. Vestnik MITHT, 2013, vol. 8, no. 2, pp. 52-57. (in Russ.).

20. Ljutikova M.N. Izuchenie sostava biologicheski aktivnyh komponentov dikorastushhih jagod Vaccinium vitis-idaea L. i Oxycoccus palustris $v$ zavisimosti ot stepeni ih zrelosti i uslovij hranenija: avtoref. diss. kand. him. nauk. [Studying the composition of biologically active components of wild berries Vaccinium vitis-idaea L. and Oxycoccus palustris, depending on their degree of maturity and storage conditions: diss. PhD in Chemistry]. Chernogolovka, 2013, 26 p. (in Russ.).

21. Lipkan G.N. Primenenie plodovo-jagodnyh rastenij v medicine. [The use of fruit plants in medicine]. Kiev, 1988, 152 p. (in Russ.).

22. Pehkonen T., Koskimäki J., Riihinen K., Pirttilä A.M., Hohtola A., Jaakola L., Tolvanen A. Physiological and Molecular Plant Pathology, 2008, vol. 72, pp. 146-150.

23. Mason G.F. J. Am. Chem. Soc. 1905, vol. 27, no. 5, pp. 613-614.

24. Gubina M.D. Himicheskij sostav, hranenie $i$ ispol'zovanie dikorastushhih plodov cherniki $i$ brusniki, proizrastajushhih v Zapadnoj Sibiri: avtoref. diss. kand. tehn. nauk. [The chemical composition, storage and use of wild fruits blueberries and cranberries growing in West Siberia: Diss. Candidate of Technical Sciences]. Leningrad, 1983, 21 p. (in Russ.).

25. Zuo Y., Wang Ch., Zhan J. J. Agric. Food Chem. 2001, vol. 50, pp. 3789-3794.

26. Bogdanova G.A., Muratov Ju.M. Brusnika v lesah Sibiri. [Lingonberries in the forests of Siberia]. Moscow, 1978, 116 p. (in Russ.).

27. Konobeeva A.B. Hozjajstvenno-biologicheskaja ocenka golubiki, cherniki, brusniki i kljukvy v uslovijah Cen-tral'noChernozemnogo regiona: avtoref. diss. kand. sel'hoz. nauk. [Economic-biological estimation of blueberries, blackberries, cranberries and cranberry in the conditions of Central Black Earth region: tesis diss. Candidate of Agricultural Sciences]. Michurinsk, 2002, 19 p. (in Russ.).

\footnotetext{
* Corresponding author.
} 
28. Jankowski K., Jocelyn Pare J.R. J. Nat. Prod. 1983, vol. 46, pp. 190-193.

29. Jensen D., Krogfelt A., Cornett C. J. Agric. Food Chem. 2002, vol. 50, pp. 6871-6874.

30. Kallio H., Nieminen R., Tuomasjukka S., Hakala M. J. Agric. Food Chem. 2006, vol. 54, pp. 457-462.

31. Romanova N.K., Reshetnik O.A., Efremov Ju.Ja., Sharafutdinova D.R. Proizvodstvo spirta i likerovodochnyh izdelij. 2004, no. 1, pp. 21-22. (in Russ.).

32. Helt G-V. Biohimija rastenij. [Plant Biochemistry]. Moskow, 2011, 290 p. (in Russ.).

33. Kozlov L.P., Kukina T.P. Himija rastitel'nogo syr'ja, 2006, no. 1, pp. 314-317. (in Russ.).

34. Kukina T.P., Popov S.A. Himija rastitel'nogo syr'ja, 2005, no. 2, pp. 310-313. (in Russ.).

35. Murphy B.T., Mackinnon Sh.L., Yan X., Hammond G.B., Vaisberg A.J, and Neto G.C. J. Agric. Food Chem. 2003, vol. 51, pp. 3541-3545.

36. Mattila P., Hellstrm J., Trrnen R. J. Agric. Food Chem. 2006, vol. 54, pp. 7193-7199.

37. Zheng Z., Shetty K. J. Agric.Food Chem. 2000, vol. 48, pp. 895-900.

38. Senchuk G.V. Biohimicheskie svojstva i sohranjaemost' dikorastushhih jagod Belorussii: avtoreferat. diss. kand. tehn. nauk. [Biochemical properties, the keeping of wild berries Belarus: abstract. diss. Candidate of Technical Sciences]. Moscow, 1973, 20 p. (in Russ.).

39. Fomicheva P.K., Batura E.V. Aktual'nye problemy nauki v agropromyshlennom komplekse. 2007, vol. 2, p. 64. (in Russ.).

40. Rasshhepkina E.A., Subbotina M.A., Rasshhepkin A.N. Tehnologija i produkty zdorovogo pitanija, 2008, no. 8, pp. 117-118. (in Russ.).

41. Matsushima M., Suzuki T., Masui A., Mine T., Takagi A. J. of Functional Foods. 2013, vol. 5, pp. 729-735.

42. Tarascou I., Mazauric J.-P., Meudec E., Souquet J.-M., Cunningham D., Nojeim S., Cheynier V., Fulcrand H. Food Chemistry. 2011, vol. 128, pp. 802-810.

43. Lee J., Finn C.E. J. of Functional Foods. 2012, vol. 4, pp. 213-218.

44. Tutel'jan V.A., Baturin A.K., Martinchik Je.A. Voprosy pitanija. 2004, no. 6, pp. 43-48. (in Russ.).

45. Amakura Y., Umino Y., Tsuji S., Tonogai Y. J. Agric. Food Chem. 2000, vol. 48, pp. 6292-6297.

46. Kuznecova N.A. Pishhevaja cennost' sokov iz dikorastushhih jagod kljukvy i cherniki. [The nutritional value of juice from wild cranberries and blueberries]. Moscow, 1975, 33 p. (in Russ.).

47. Borowska I., Szajdek A. Pol. J. Natur. Sci. 2003, no. 14, pp. 521-528.

48. Ek S., Kartimo H., Mattila S., Tolonen A. J. Agric. Food Chem. 2006, vol. 54, pp. 9834-9842.

49. Wang Y., Catana F., Yang Y., Roderick R. J. Agric. Food Chem. 2002, vol. 50, no. 3, pp.431-435.

50. Hakkinen S.H., Karenlampi S.O., Heinonen I.M., Mykkanen H.M., Torronen A.R. J. Agric. Food Chem., 1999, vol. 47, no. 6, pp. 2274-2279.

51. Ermolaeva G.A. Pivo i napitki. 2004, no. 1, pp. 48-50. (in Russ.).

52. Marsov N.G. Fitohimicheskoe izuchenie i biologicheskaja aktivnost' brusniki, kljukvy i cherniki: avtoref. dis. kand. farm. nauk. [Phytochemical studies and biological activity of cranberries, cranberries and blueberries: diss. Candidate of Pharmaceutical Sciences.]. Perm', 2006, 24 p. (in Russ.).

53. Prior R.L., Lazarus S.A., Cao G., Muccitelli H., Hammerstane J.F. J. Agric. Food Chem. 2001, vol. 49, pp. 1270-1276.

54. Wang Sh.Y., Stretch A.W. J. Agric. Food Chem. 2001, vol. 49, pp. 969-974.

55. Yuan W., Zhou L., Deng G., Wang P., Creech D., Li Sh. Pharmaceutical Crops. 2011, vol. 2, pp. 11-23.

56. Vorsa N., Polashock J., Cunningham D., Roderick R. J. Am. Soc. Hortic. Sc. 2003, vol. 128, pp. 691-697.

57. Filatova I.A., Filippova R.L., Kolesnov A.Ju., D'jachenko M.A. Pishhevaja promyshlennost'. 2006, no. 1, pp. 24-26. (in Russ.).

58. Avilova S.V. Ivanova S.V. Izvestija TSHA, no. 2, 2005, pp. 59-67. (in Russ.).

59. Filipcova G.G. Osnovy biohimii rastenij. [Fundamentals of Plant Biochemistry]. Minsk, 2004, 136 p. (in Russ.).

60. Bratus I.N. Himija dushistyh veshhestv. [Chemical fragrances]. Moscow, 1992, 240 p. (in Russ.).

61. Metlickij L.V., Ozereckovskaja O.L., Karableva N.P. Biohimija immuniteta, pokoja, starenija rastenij. [Biochemistry immunity, peace, aging plants]. Moscow, 1984, 264 p. (in Russ.).

62. Semenov A.A. Ocherk himii prirodnyh soedinenij. [Outline of chemistry of natural compounds.]. Novosibirsk, 2000, 664 p. (in Russ.).

63. Pilat T.L., Ivanov A.A. Biologicheski aktivnye dobavki k pishhe (teorija, proizvodstvo, primenenie). [Biologically active food supplements (theory, production, application)]. Moscow, 2002, 710 p. (in Russ.).

64. Kurbatova E.I. Razrabotka biotehnologicheskogo processa poluchenija polufabrikatov likerovodochnyh izdelij na osnove fermentativnoj obrabotki plodovo-jagodnogo syr'ja: avtoref. diss. kand. tehn. nauk. [The development of biotechnological production process of semi-finished liquors by enzymatic treatment of fruit and berries: diss. Candidate of Technical Sciences]. Moscow, 2005, 22 p. (in Russ.).

65. Terent'eva V.M. Sibirskij vestnik sel'skohozjajstvennoj nauki. 2008, no. 10, pp. 113-116. (in Russ.).

66. Rabinovich A.M. Lekarstvennye rastenija Rossii. [Herbs Russia]. Moscow, 2001, 319 p. (in Russ.).

67. Kiriljuk L.I., Buganova A.A., Zaharina T.N., Bahtina E.A. Lesnoe hozjajstvo. 2005, no. 6, pp. 29-30. (in Russ.).

68. Grigorjuk G.P., Starostina E.B., Zaikina N.V. Sbornik materialov II Vserossijskoj konferencii «Himija i tehnologija rastitel'nyh veshhestv». [Collection of Materials of II All-Russian Conference "Chemistry and Technology of Plant Substances"]. Kazan', 2002, p. 136. (in Russ.). 
69. Kol'man O.Ja., Ivanova G.V. Vestnik KrasGAU. 2013, no. 4, pp. 179-185. (in Russ.).

70. Kabanova N.I. Lec, nauka, molodezh'. 1999, vol. 2, pp. 222-224. (in Russ.).

71. Bykov A.T., Bova S.I., Shamko I.A. Medicinskij zhurnal. 2012, no. 3, pp 4-7. (in Russ.).

72. Viljakainen S., Visti A., Laakso S. Acta Agriculturae Scandinavica: Section B, Soil and Plant Science. 2002, vol. 52, pp. 101-109.

73. Dorofejeva K., Rakcejeva T., Galoburda R., Dukalska L., Kviesis J. Food Science. 2011, vol. 1, pp. 433-440.

74. Côté J., Caillet S., Doyon G., Dussault D., Sylvain J.-F., Lacroix M. Food Control. 2011, vol. 22, pp. 1413-1418.

75. Côté J., Caillet S., Doyon G., Dussault D., Sylvain J.-F., Lacroix M. Food Control. 2012, vol. 23, pp. 419-428.

76. Lacombe A., Vivian C.H. Wu, Tyler S., Edwards K. International Journal of Food Microbiology. 2010, vol. 139, pp. 102-107.

77. Côté J., Caillet S., Dussault D., Sylvain J.-F., Lacroix M. Food Research International. 2011, vol. 44, pp. $2922-2929$.

78. Minaeva V.G. Lekarstvennye rastenija Sibiri. [Medicinal Plants of Siberia]. Novosibirsk, 1991, 429 p. (in Russ.).

79. Zhang K., Zuo Y. J. Agric. Food Chem. 2004, vol. 52, pp. 222-227.

80. Matsushima M., Suzuki T., Masui A., Mine T., Takagi A. J. of Functional Foods. 2013, vol. 5, pp. 729-735.

81. Georgievskij V.P. Biologicheski aktivnye veshhestva lekarstvennyh rastenij. [Biologically active substances of medicinal plants]. Novosibirsk, 1990, 327 p. (in Russ.).

82. Kalt W. Hortic. Revs. New York, 2001, vol. 27, pp. 269-315.

83. Shabrov A.V. Biohimicheskie osnovy dejstvija mikrokomponentov pishhi. [The biochemical basis of the action of micro-components of food]. Moscow, 2003, 184 p. (in Russ.).

84. Vu K.D., Carlettini H., Bouvet J., Côté J., Doyon G., Sylvain J.-F., Lacroix M. Food Chemistry. 2012, vol. 132, pp. 959-967.

85. Johnson-White B., Buquo L., Zeinali M., Ligler F.S. Anal. Chem. 2006, vol. 78, pp. 853-857.

86. Erickson B. Anal. Chem. 2006, vol. 78, pp. 638.

87. Yeap Foo L., Lu Y., Howell A.B., Vorsa N. J. Nat. Prod. 2000, vol. 63, pp. 1225-1228.

88. Chen C.H., Ho D.R., Lin W., Ho D.R., Chang P.J., Huang Y.J. J. of Infection and Chemotherapy. 2013, vol. 19, pp. 812-817.

89. Mathison B., Kimble L., Kaspar K., Khoo C., Chew B. Nutrition Research. In Press. Accepted Manuscript. 2014, pp. 1-31.

90. Kim S.H., Ha U-S., Lee H.L., Sohn D.W., Lee S.-J., Kim H.W., Han H.C., Lee C.B., Cho Y.-H. J. of Infection and Chemotherapy. 2011, vol. 17, pp. 322-326.

91. Takahashi S., Hamasuna R., Yasuda M., Arakawa S., Tanaka K. J. of Infection and Chemotherapy. 2013, vol. 19, pp. 112-117.

92. Basu A., Betts N.M., Ortiz J., Simmons B., Wu M., Lyons T.J. Nutrition Research. 2011, vol. 31, pp. 190-196.

93. Elberry A., Abdel-Naim A., Abdel-Sattar E., Nagy A., Mosli H., Mohamadin A., Ashour O. Food and Chemical Toxicology. 2010, vol. 48, pp. 1178-1184.

94. Kowalska K., Olejnik A., Rychlik J., Grajek W. Food Chemistry. 2014, vol. 148, pp. 246-252.

95. Artemio Z., Tulio Jr., Jablonskia J., Jacksona L., Lauren S., Changa C., Edirisinghec I. Burton-Freemanc B. Food Chemistry. 2014, vol. 157, pp. 540-552.

96. Kivimäki A., Siltari A., Ehlers P., Korpela R., Vapaatalo H. J. of Functional Foods. 2014, vol. 7, pp. 238-245.

97. Kivimäki A., Siltari A., Ehlers P., Korpela R., Vapaatalo H. J. of Functional Foods. 2013, vol. 5, pp. 1432-1440.

98. Khoo C., Falk M. Polyphenols in Human Health and Disease. 2014, vol. 2, pp. 1049-1065.

99. He J., Rodriguez-Soana L.E., Giusti M.M. J. Agric. Food Chem. 2007, vol. 55, pp. 4443-4452.

100. Ivanova R.I., Prida A.I. Pishhevye ingredienty: syr'e i dobavki. 2004, no.2, pp. 76-78. (in Russ.).

101. Kivimäki A., Siltari A., Ehlers P., Korpela R., Vapaatalo H. J. of Functional Foods. 2014, vol. 7, pp. 238-245.

102. Lipson S.M., Sethi L., Cohen P., Gordon R.E., Tan I.P., Burdowski A., Stotzky G. Phytomedicine, 2007, vol. 14, pp. 23-30.

103. Su X., Howell A.B., D'Souza D.H. Food Microbiology. 2010, vol. 27, pp. 535-540.

104. Murashev S.V., Bolejko L.A., Verzhuk V.G., Zhestkov A.S. Konditerskoe proizvodstvo. 2011, no. 2, pp. 8-11. (in Russ.).

105. Murashev S.V., Zhemchuzhnikova M.E., Verzhuk V.G. Ovoshhi Rossii. 2013, no. 4 (21), pp. 50-51. (in Russ.).

106. Kiseleva T.F., Grigor'eva M.S., Zolin A.G. Tehnika i tehnologija pishhevyh proizvodstv. 2011, no. 1, pp. $114-117$. (in Russ.).

107. Lupinskaja S.M. Tehnika i tehnologija pishhevyh proizvodstv. 2010, vol. 18, no. 3, pp. 13-17. (in Russ.).

108. Macejchik I.V., Dobrydina E.S. Vestnik KrasGAU. 2009, no. 4, pp. 208-213. (in Russ.).

109. Kol'man O.Ja., Ivanova G.V. Vestnik KrasGAU. 2013, no. 5, pp. 218-222. (in Russ.).

110. Butenko L.I., Ligaj L.V. Mezhdunarodnyj zhurnal jeksperimental'nogo obrazovanija. 2011, no. 6, pp. 82-84. (in Russ.).

111. Kravchenko S.N., Himich A.N. Fundamental'nye issledovanija. 2008, no. 12, p. 46. (in Russ.).

112. Sorokopud A.F., Astaf'eva A.N. Tehnika i tehnologija pishhevyh proizvodstv. 2013, no. 1, pp. 1-5. (in Russ.).

113. Kravchenko S.N., Popov A.M., Himich A.N. Izvestija vuzov. Pishhevaja tehnologija. 2009, no. 2-3, pp. $43-46$. (in Russ.). 
114. Ovsjannikova E.A., Ponamareva M.V., Potapov A.N., Kiseleva T.F. Vestnik KrasGAU. 2013, no. 1, pp. $169-173$. (in Russ.).

115. Kijashkina L.A., Cugkieva V.B., Datieva B.A., Shabanova I.A. Izvestija Gorskogo gosudarstvennogo agrarnogo universiteta. 2013, vol. 50, no. 1, pp. 304-307. (in Russ.).

116. Ovsjannikova E.A., Kiseleva T.F., Potapov A.N., Djuzhev A.V. Tehnika i tehnologija pishhevyh proizvodstv. 2012, no. 4, pp. 1-4. (in Russ.).

117. Kushnereva E.V., Guguchkina T.I., Pautov R.Ju. Al'manah sovremennoj nauki i obrazovanija. 2010, no. 7 (38), pp. 81-83. (in Russ.).

118. Guguchkina T.I., Kushnereva E.V., Pautov R.Ju. Plodovodstvo i vinogradarstvo Juga Rossii. 2011, no. 8, pp. $126-133$. (in Russ.).

119. Gimaev I.N., Romanova N.K., Reshetnik O.A. Vestnik Kazanskogo tehnologicheskogo universiteta. 2004, no. 1, pp. 214-218. (in Russ.).

Received September 8, 2014 
